Cornell University Law School Scholarship@Cornell Law: A Digital Repository

4-9-2013

\title{
Debt, Deflation, and Debacle: Of Private Debt Write-Down and Public Recovery
}

Richard W. Vague

Gabriel Investments

Robert C. Hockett

Cornell Law School, Robert-Hockett@lawschool.cornell.edu

Follow this and additional works at: http://scholarship.law.cornell.edu/facpub

Part of the Banking and Finance Commons, and the Law and Economics Commons

\section{Recommended Citation}

Vague, Richard W. and Hockett, Robert C., "Debt, Deflation, and Debacle: Of Private Debt Write-Down and Public Recovery" (2013). Cornell Law Faculty Publications. Paper 1395.

http://scholarship.law.cornell.edu/facpub/1395 


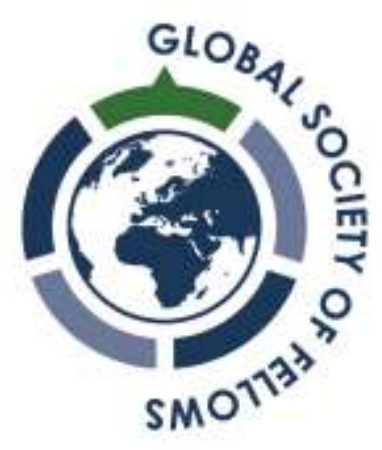

\section{Debt, Deflation, and Debacle: Of Private Debt Write-Down and Public Recovery}

Prepared by:

\section{Richard Vague}

Managing Partner

Gabriel Investments

The Mellon Building

1735 Market Street, Suite 2501

Philadelphia, PA 19103

\section{Robert Hockett}

Professor of Law

Cornell University Law School

316 Myron Taylor Hall

Ithaca, NY 14853

April 9, 2013

All statements, findings, and conclusions in this report are those of the authors and do not necessarily reflect those of the Global Interdependence Center. 


\title{
Debt, Deflation, and Debacle: Of Private Debt Write-Down and Public Recovery
}

\author{
Robert Hockett \& Richard Vague*
}

\section{Introduction: Private Debt \& Public Debate}

Most public discussion of the nation's continuing financial and macroeconomic troubles focuses rightly on debt. It focuses wrongly, however, on public debt. The true source of the nation's ills is private debt overhang among millions of American households. ${ }^{1}$ Private debt is the provenance of both (a) the asset price bubble and bust in whose aftermath we still struggle, and (b) the fact that we're still struggling. Public sector debt growth since 2009 is merely a symptom - the product of thus far failed treatment - of this fundamental condition.

The dynamic pursuant to which private debt overhang underwrites ongoing slump, though still underappreciated, is not unfamiliar. A surplus of credit available to consumers and home-buyers from the mid-1990s onward at first facilitated real growth in home-ownership, consumer spending, and associated asset prices. By the late 1990s, however, cheap credit had begun fueling "artificial" growth too, as some buyers began buying homes and associated assets with a view less to consuming or investing than to reselling. Thereupon prices rose less in response to "fundamentals" than to unsustainable price rises themselves, per the familiar self-referential "feedback" dynamic characteristic of all asset price bubbles and busts. Then when the bubble inevitably burst, prices shot downward while debt loads did not. Millions were left deep "underwater," where they slosh to this day and don't spend.

What then to do? Relative to the state of the public discussion, the answer is surprisingly obvious. Private debt must be restructured and largely forgiven, on a scale commensurate with those asset price plummets that were the crash. This is, virtually by definition, the only sustainable way to eliminate our now crippling private debt overhang and thus end the slump. The only alternatives are intolerable: (a) continuing slump, with all of the waste and continuing tragedy it entails; or (b) further asset price bubbles and busts, of the sort in which all efforts to pare overhang artificially from the asset side of the balance sheet alone - e.g., through non-supplemented monetary policy - ultimately issue.

\footnotetext{
Hockett is Professor of Financial and Monetary Law at Cornell University Law School, Consulting Counsel
at the International Monetary Fund, Fellow at The Century Foundation, Fellow with the Global Interdependence Center at the Federal Reserve Bank of Philadelphia, and recent Resident Consultant at the Federal Reserve Bank of New York. Vague is ... We thank our co-authors on other projects, as well as other associates, including Daniel Alpert, Steve Clemons, Daniel Dillon, Nouriel Roubini, Sherle Schweninger ... ; and participants in the Richmond Conference sponsored by the Global Interdependence Center of the Federal Reserve Bank of Philadelphia on April 19, 2013, for helpful comment and criticism.

1 See, e.g., Alpert, Hockett, \& Roubini "The Way Forward: Moving from the Post-Bubble, Post-Bust Economy to Renewed Growth and Competitiveness," White Paper, New America Foundation (2011), at http://papers.ssrn.com/sol3/papers.cfm?abstract id=1987139; and Clemons \& Vague, "How to Predict the Next Financial Crisis," working paper, at _. Also Hockett, "Delivering from De-levering," Benzinga Financial News Website, August 25, 2011, at http://www.benzinga.com/markets/bonds/11/08/1883933/delivering-from-delevering ; and Daniel Alpert, The Age of Oversupply (2013).
} 
It is in hopes of averting these two intolerable alternatives that we offer this paper. We show both (a) that private debt overhang is the problem, and (b) how, finally, to eliminate this problem. We do so pursuant to the following agenda:

Part II elaborates more fully on the role played by private debt first in fomenting financial crisis, then in protracting the post-crisis slump. It begins by first modeling the dynamic through which that occurs. It then empirically corroborates the presence and operation of this dynamic in the nation's most devastating bubbles, busts, and ensuing deflations - in particular those associated with the "Great Depression" of the 1930s and the "Great Recession" of the present day.

Part III then documents the magnitude of the post-bubble private debt overhang with which we still struggle. This overhang is by far the most causative - indeed, at this point, the sole salient - cause of our ongoing slump.

Part IV next elaborates a menu of concrete policy actions that can and must be taken to eliminate our private debt overhang and restore healthy growth to the macroeconomy. All of these involve maximal principal write-down on unsustainable private debt loads, at minimal public cost and minimal risk of moral hazard or long-term liquidity shortage. Part $\mathrm{V}$ then concludes.

\section{Private Debt \& Public Debacle}

Since the crash of 2008 and ensuing slump, many have been exercised by the role of "debt" both in the run-up and in the sequel with which we still struggle. Surprisingly, however, the focus of this discussion has been on the wrong debt. It's been on public, rather than private debt. This is what all of the storm and stress in debates between "stimulators" and "austerians" has been about. Is growth best restored by trimming government debt and balancing budgets now, or should we engage in more "Keynesian" stimulus, then balance our budgets later with the benefit or revenue growth wrought by the same? This is the false question with which we are daily confronted.

Obviously public debt can matter in the long term while restored growth matters more in the short term - even for purposes of debt-reduction itself. In that sense, at least, the stimulators have the better of their argument with the austerians. But what both sides ignore in this contest is private debt, which must be trimmed now, in the immediate term, if there is to be any sustainable growth or reduction of public debt in the long term or even the medium term.

This central role played by private debt, both in underwriting our ongoing slump and in fomenting the bubble and bust that have brought us that slump, is the proverbial elephant in the room of which few public figures, it seems, see fit to speak. In this Part we aim, then, first to direct attention to where it belongs. We do so by showing the central role played by private debt in both (a) bringing us where we are now, and (b) trapping us in the place where it's left us. 
We start in Subpart A by briefly elaborating the dynamic that links private debt to bubble, bust, and ensuing depression. We then turn in B to empirically demonstrating this mechanism's continuing presence and operation.

\section{A. The Links in the Chain: From Debt to Deflation}

The nation, the states, our cities and even the globe remain trapped in the debt-deflationary fallout of a financial crisis whose epicenter comprised and comprises a surprisingly limited number of U.S. localities. ${ }^{2}$ The crisis itself was the culmination of a credit-fueled asset price bubble focused largely, though not quite exclusively, upon residential real estate. As further documented in Parts III and IV, the latter both was, and remains, disproportionately rooted in "sun belt" and "sand" states. In this as in other respects, the lead-up to the present situation replicated developments that led up to its closest predecessors in terms of sheer magnitude - the bubble, bust, and ensuing debt deflation experienced by the U.S. and wider world during the 1920s-1930s. ${ }^{3}$

The credit and counterpart private debt buildups that occur at the front ends of these episodes can derive from a number of sources, though persistent trade imbalance and associated capital surpluses seem to be common to all cases - surpluses enjoyed by the post-war U.S. during the 1920s, and by some Asian nations beginning with Japan during the 1980s and after. In our most recent episode, the credit flows seem to have stemmed at least partly from surpluses accumulated over the course of the 1990s by beneficiaries of the newly liberalized global economy following the breakup of the old "eastern" bloc of once-socialist nations. ${ }^{4}$ Flows of this credit were particularly difficult for developed country monetary authorities like the U.S. Federal Reserve to sterilize, given the openness of their financial markets to the wider world. ${ }^{5}$ The theretofore unprecedented "global savings glut," as

$2 \quad$ This Part draws in part upon Hockett, "It Takes a Village: Municipal Condemnation Proceedings and Public/Private Partnerships for Mortgage Loan Modification, Value Preservation, and Local Economic Recovery," 18 Stanford J. L., Bus. \& Fin. 121 (2013), at http://papers.ssrn.com/sol3/papers.cfm?abstract id=2038029; and Hockett, "Paying Paul and Robbing No One: An Eminent Domain Plan for Underwater Mortgage Loans That Can Benefit Everyone," 18 Current Issues in Econ. \& Fin. _ (Federal Reserve Bank of New York) (2013), at http://papers.ssrn.com/sol3/papers.cfm?abstract id=2173358.

As more statistics related infra, Part III indicate, affected communities are disproportionately, though not solely, located in Arizona, California, Florida, Georgia, Nevada and several other states. In this sense, the situation is not unlike that which followed the nation's last residential real estate bubble and bust, in the late 1920 s. See infra, Part III. Also Hockett, "A Fixer-Upper for Finance," 87 Wash. U. L. Rev. 1 (2010), at http://papers.ssrn.com/sol3/papers.cfm?abstract id=1367278; and Hockett, "Bailouts, Buy-Ins, and Ballyhoo," 52 Challenge 36 (2009), at http://papers.ssrn.com/sol3/papers.cfm?abstract id=1276285.

3 See sources cited idem. Also Alpert, Hockett, \& Roubini, supra note 1; Clemons \& Vague, supra note 1; and Alpert, supra note 1 . The salient features of both episodes also bear striking resemblances to those associated with the "lost decades" experienced by Japan since the early 1990s. See again sources cited idem.

$4 \quad$ Notably China and the East Asian "tiger" economies, but also others. See again Alpert, Hockett, \& Roubini, supra note 1; Hockett, supra note 1; and Alpert, supra note 1.

$5 \quad$ Idem. Also Hockett, "Bretton Woods 1.0: An Essay in Constructive Retrieval," 16 N.Y.U. Journal of Legislation \& Public Policy _ (2013) (forthcoming), at http://papers.ssrn.com/sol3/papers.cfm?abstract_id=1805962. 
then Federal Reserve Governor Ben Bernanke christened it in $2005,{ }^{6}$ served as the predicate to a classic recursive collective action problem of the kind on which one of the present authors has written at length elsewhere. $^{7}$

The hallmark of these problems is their capacity to bring about situations in which multiple uncoordinated decisions - even blameless, individually rational such decisions - iteratively aggregate into collectively self-damning outcomes. ${ }^{8}$ Arms races, "bums' rushes," bank runs and hyperinflations are familiar examples of this common phenomenon - as are, usually in non-recursive form, those gametheoretic perennials known as the "prisoner's dilemma" and "tragedy of the commons." ${ }^{9}$ So too, we now know, are asset price bubbles and busts. ${ }^{10}$

The problem in the present instance, with whose sequelae again we continue to struggle, unfolded on the one hand pursuant to the classic pattern, while on the other hand on the strength of the credit glut just noted. ${ }^{11}$ The dynamic, in brief, is as follows.

First, when credit costs - in the form of low interest charges, high obtainable loan-to-value ratios (LTVS), or both - remain inexpensive over some lengthy interval, and at some point early on in that interval some discrete class of assets like real estate and the financial instruments appurtenant to it begin rising in value at more rapid rates than effective interest or collateral haircut rates, it quickly becomes rational for more individuals than before to begin borrowing and buying the assets in question. Moreover, and more ominously for present purposes, it also becomes rational for at least some individuals - so-called "speculative buyers" - to borrow to buy only to sell, with a view ultimately to profiting on the emerging, then widening spread between low borrowing costs and high, then

$6 \quad$ See Bernanke, The Global Savings Glut and the U.S. Current Account Deficit: Remarks at the Sandridge Lecture, Virginia Association of Economists, March 10, 2005, available at: http://www.federalreserve.gov/boarddocs/speeches/2005/200503102/.

See Hockett sources cited supra, note 2. Also Hockett, "Recursive Collective Action Problems," 5 J. App. Econ. 1, at http://papers.ssrn.com/sol3/papers.cfm?abstract id=2239849; and Hockett, "Bubbles, Busts, and Blame," 37 Cornell Law Forum 14 (2010), at http://papers.ssrn.com/sol3/papers.cfm?abstract id=1805930. $8 \quad$ Idem.

$9 \quad$ The standard renditions of the prisoner's dilemma and tragedy of the commons need not involve feedback effects and accordingly need not be self-worsening. Indeed, collective action-problem-solving conventions can sometimes emerge pursuant to iteration of these situations. What we are calling recursive collective action problems, by contrast, simply self-worsen with iteration, hence involve either indeterminate equilibria or no equilibria at all. See again sources cited supra, notes 5 and 7.

10 Some of course do not simply "now" know this, but long have observed it. See the work of Geanakoplos cited infra, note 13; and the important work on procyclicality done by my colleague Tobias Adrian with Hyun Shin, e.g. Adrian \& Shin, "Procyclical Leverage and Value at Risk," FRBNY Staff Reports, No. 338 (2011), available at http://www.newyorkfed.org/research/staff reports/sr338.html; Adrian et al., "Monetary Cycles, Financial Cycles, and the Business Cycle," FRBNY Staff Reports, No. 421 (2010), available at http://www.newyorkfed.org/research/staff reports/sr421.html; and Adrian et al., "Financial Intermediation, Asset Prices, and Macroeconomic Dynamics," FRBNY Staff Reports, No. 422 (2010), available at http://www.newyorkfed.org/research/staff reports/sr422.html. See also Shin, Risk and Liquidity (2010). See Alpert, Hockett, \& Roubini, supra note 1; Hockett, supra note 1; Alpert, supra note 1. 
accelerating capital appreciation rates. ${ }^{12}$ And these comparatively few speculative buyers, crucially, come increasingly to determine the prices that even conservative buyers must pay - and indeed borrow to pay. ${ }^{13}$

Once even a relatively small threshold number of speculative market actors begin acting on rational "spread-legging" calculations like these, the ensuing credit-fueled asset appreciation process can become self-accelerating. It can do so, indeed, for as long as the credit that fuels it remains overabundant. More buying then comes to mean more price rises, which means greater spreads between low levering costs and high capital gains, which in turn brings on more expectation of yet further price rises, which issues in further accelerated buying ${ }^{14}$... and so on, for as long as (a) the levering remains inexpensive, and (b) there remain further, untapped prospective new entrants to affected markets. ${ }^{15}$

Figure 1 roughly pictures the dynamic.

12 Idem. The assets in question might first begin (moderately) rising in value for reasons rooted in "fundamentals" - for example, demographic changes that bring more first-time buyers into housing markets. The problem is that over-abundant credit can then enable even initially moderate price rises rooted in fundamentals to accelerate into much steeper price rises rooted in credit-enabled, self-fulfilling price-rise expectations themselves.

13 This point is critical, particularly when questions of blame are on the agenda as below in Part IV. One needed not be a "house-flipper" to get caught up in and thus inadvertently further contribute to the mortgage bubble dynamic, any more than one need be a "bread-flipper" to be drawn into and thereby contribute further to the dynamic of a consumer price hyperinflation. Perfectly sober, even regretful parties can be prompted to buy now rather than later simply by rational recognition of the fact that, so long as the inflation or hyperinflation is underway, prices will be so much higher in future as to render it sensible to buy now rather than later. It also bears noting that not only speculators, but fraudsters as well can disproportionately determine these higher market prices that the great majority of sober and honest purchasers must pay. See Hockett, sources cited supra, notes 2 and 7.

Credit for first rigorously modeling the disproportionate influence of "optimists" in a general equilibrium model with heterogeneous investors rests with the prescient and ever-brilliant John Geanakoplos. See Geanakoplos, "Promises, Promises," 305-07, in The Economy as a Complex Evolving System II, pp. $285-320$ (W. B. Arthur et al., eds., 1997); Geanakoplos, "Liquidity, Default, and Crashes: Endogenous Contracts in General Equilibrium," in Advances in Economics and Econometrics: Theory and Applications, Econometric Society Monographs, Eighth World Conference, 2:170 (Cambridge U. Press, 2005); and, more recently, Geanakoplos, "The Leverage Cycle," NBER Macroeconomics Annual, pp. 1-65 (2010), at 43. The same works highlight the importance of distinguishing between interest and leverage (collateral) in some critical contexts. They do not reference fraudsters, but the logic carries over to their case as well.

$14 \quad$ Note again that the accelerated buying might be done by speculators or fraudsters acting pursuant to profit motives, but also might be done by ordinary "buy and hold" buyers who simply decide to buy sooner rather than later in order to avoid having to pay more at later dates. In this sense the bubble is, again, much like a consumer price hyperinflation, which can be fueled not only by commodities speculators but also by ordinary consumers hoping to preempt higher payment requirements apt to set in at later dates.

15 This is of course what accounts for some mortgage originators' having sought ever more "marginal" borrowers to whom to lend on ever more risky, "sub-prime" terms - and even non-marginal buyers to switch into more marginal, higher risk higher return mortgage arrangements - as the pool of prospective new buyers shrank and the bubble neared its prospective-new-entrant-determined natural limiting perimeter. It also accounts for the uptick in fraudulent credit practices as the limits of pools of new entrants, and thus of the bubble itself, were at long last approached. See Hockett, "A Fixer-Upper for Finance," supra note 2. 
Figure 1

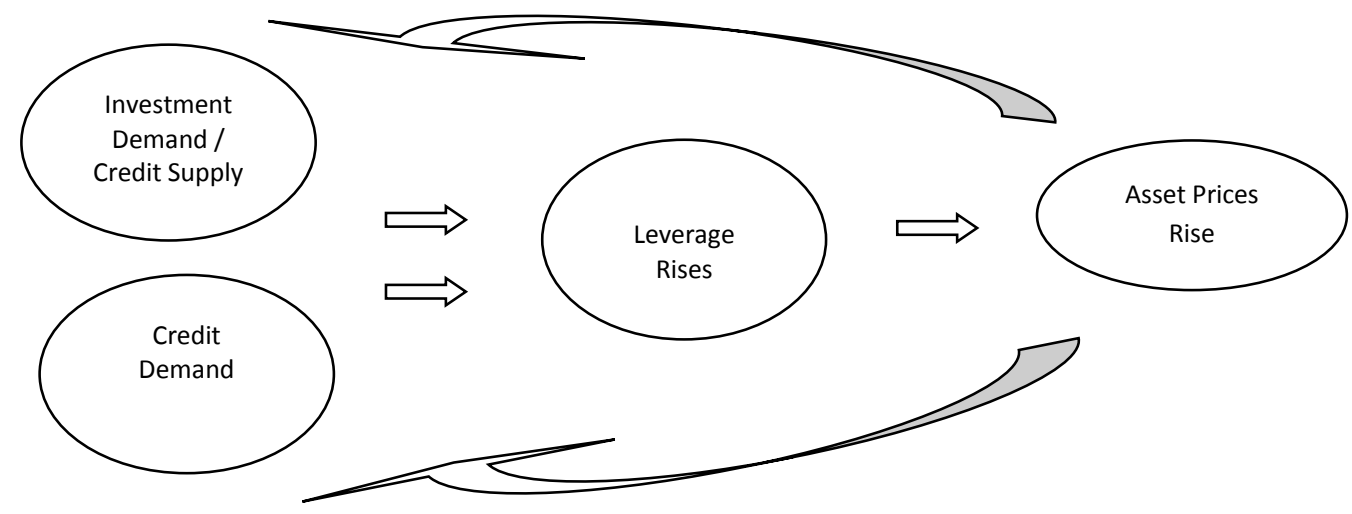

The asset price bubbles of the later 1990s and early 2000s were self-accelerating pursuant to precisely this "feedback loop" pattern. As more investors noticed the profits to be made by purchasing residences, mortgage-backed securities (MBS), or associated instruments on low cost credit and then reselling, more were drawn into or otherwise affected by such transactions. Some surely were prompted by speculative profit-seeking for their own accounts. Others were pressed into participating by clients on whose accounts they were trading. ${ }^{16}$ Still others were pressed in effect by the speculators themselves, via the disproportionate impact the latter's transactions exerted on prices that even ordinary folk had to pay - and, increasingly, to borrow to pay. ${ }^{17}$ And as more came to transact on these terms, prices naturally rose higher, at accelerating rates, increasing profit opportunities yet further.

In effect, a spontaneously emergent "Ponzi," or "pyramid" process developed in the nation's largest primary and secondary real estate markets over the 1990s and early 2000s - a process that, crucially, requires no actual Ponzi or schemer to commence or persist. ${ }^{18}$ The non-necessity of any such Ponzi or schemer in these processes is important. It is precisely the sense in which processes of this sort stem from classic coordination problems - problems that result from, rather than defying, individual rationality, even ethically blameless such rationality. That fact bears crucially on the relevance of "moral hazard" considerations to debt write-down measures of the sort that we advocate below in Part IV.

None of this is to say there was no blame or irrationality during our recent asset price bubbles, or during their predecessors over the 1920s and earlier 1990s; there always is, bubble or no. ${ }^{19}$ It is only

16 Much anecdotal evidence suggests that many hedge fund managers sought to pull out of or even short real estate during the late stages of the bubble, only to be told by their clients that they would withdraw their funding and invest elsewhere were the managers to do so. See, e.g., Hockett, "A Fixer-Upper for Finance," supra note 2; and Geanakoplos, "Promises, Promises," supra note 13.

17 See sources cited supra, note 13.

18 This is a core message of Hockett, "A Fixer-Upper for Finance," supra note 2, in which the term "spontaneously emergent Ponzi process" is introduced. See also other sources cited supra, notes 2, 5, and 7. Blame there might have been, but it is altogether unnecessary to explain what happened over the course of our most recent bubble and bust. The idea of a "naturally occurring Ponzi process" figures prominently Shiller, Irrational Exuberance (2000), which introduces it.

19 See again sources cited supra, notes 2,5 , and 7. 
to say that these would have been inessential, and in that sense didn't lie at the core of these crises. ${ }^{20}$ All that is needed is underpriced credit, which tends to remain underpriced for as long as capital surpluses continue to grow - as they did in the lead-ups to our worst recent crises. Hence there is no need to point fingers at anyone - home buyer, lender, secondary market investor, or even exporter - in explaining what happens. There is only a need to clear up the wreckage that these individuals are no better positioned collectively to clear than they were to prevent.

"Wreckage?" We say that because wreckage of a sort is precisely what happens once the pool of prospective new asset buyers - in the U.S. circa 2006, home buyers - is finally exhausted, such that creditors no longer can lend in the blithe expectation that underlying prices will continue to rise. Once the proverbial "music" stops, and prices in consequence peak and then plunge, millions of asset purchasers - again, in the U.S. most recently, home-buyers - cannot but then find themselves suddenly "underwater," hunkering down under debt overhang with negative equity. Their variably priced assets plummet in value, while their fixed debt obligations do not. That leaves them with more in debt obligations - often very much more - than in underlying equity. And that in turn leaves them unable to spend and drive growth in the way they have done prior to the bust, as we shall see amply demonstrated in Part III. Public debt then grows simply to take up the slack - to prevent debtdeflation's morphing into depression. Trim the private debt, that means, and the public debt won't be as necessary.

\section{B. Finding the Links in the World: What the Data Show}

We now turn to empirically demonstrating the actual presence and operation of the dynamic just sketched in II.A. The evidence, we find, is compelling - particularly when we pay special attention to those episodes of bubble, bust, and ensuing debacle that people call "great." ${ }^{21}$

We begin, then, with consumer and, especially, mortgage debt trends in the lead-ups to the "great" crises of 1929 onward and 2008 onward. We consider these first in relation to incomes - as debt-to-income (DTI) ratios - and in relation to credit-purchased assets - as loan-to-value (LTV) ratios among purchasers. We then look at private debt aggregates in relation to the nation-level analogue to household incomes - gross domestic product (GDP). Along all these dimensions, the parallels between the lead-up to 1929 on the one hand, and that to 2008 on the other, are striking.

We then turn to asset prices during the two periods, comparing these to reasonable proxies for "fundamental" value - viz. P/E ratios in the case of corporate equities, building costs and comparable rental prices in the case of homes. Once again the parallels between 1929 and 2008 are striking, suggesting that abundant credit "artificially" fueled price rises during these periods such as to leave

\footnotetext{
$20 \quad$ Idem.

$21 \quad$ We draw here in part upon Clemons \& Vague, supra note 1; Alpert, Hockett, \& Roubini, supra note 1; and Hockett \& Dillon, "Income Inequality \& Market Fragility: Some Empirics in the Political Economy of Finance," working paper, at http://papers.ssrn.com/sol3/papers.cfm?abstract id=2204710.
} 
significant debt overhang once prices dropped and debt loads did not. That sets us up nicely for our examination in Part III of where we are now, and in Part IV of how best to climb out.

We begin with our most recent episode. According to the Survey of Consumer Finances, the lead-up to 2008 saw borrowing rates peak among families with above median incomes under the top income and wealth brackets - "the great middle class." ${ }^{22}$ By net worth, debt accumulation was highest among those in the third quartile, while, as in any given survey year, families in the lowest income, wealth, and education tiers were less likely to accumulate debt. ${ }^{23}$

Some graphics help sharpen the picture. Figure 2 indicates, for example, that between 2004 and 2007 the debt payments to income (DTI) ratio - a common indicator of debt burden - rose for all families save those in the bottom 20 percent and the top 10 percent of the income distribution. As middle-income families took on more debt relative to income, the nation's lowest and highest earners reduced their debt burden. With the onset of crash and recession between 2007 and 2010, the trend then reversed, with the DTI ratio for those at the bottom skyrocketing while earners in the $60^{\text {th }}$ to $90^{\text {th }}$ percentile began gradually to lower debt payments in relation to income - a development that is consistent with the debt-deflation part of our story to which we'll turn in due course.

$22 \quad$ Bricker et al., "Changes in U.S. Family Finances from 2007 to 2010: Evidence from the Survey of Consumer Finances,"98 (2) Federal Reserve Bulletin 2, 55 (June 2012), available at <http://federalreserve.gov/pubs/bulletin/2012/PDF/scf12.pdf>.

By far the greater part of family debt consists of home-secured debt and installment borrowing (consumer durables and education loans); see Bricker et al., idem at 65. Among lower income groups, education loans account for the largest percentage of installment borrowing, while among the top four quintiles, vehicle loans account for the largest percentage; see Bricker et al., idem at 66. 
Figure 2

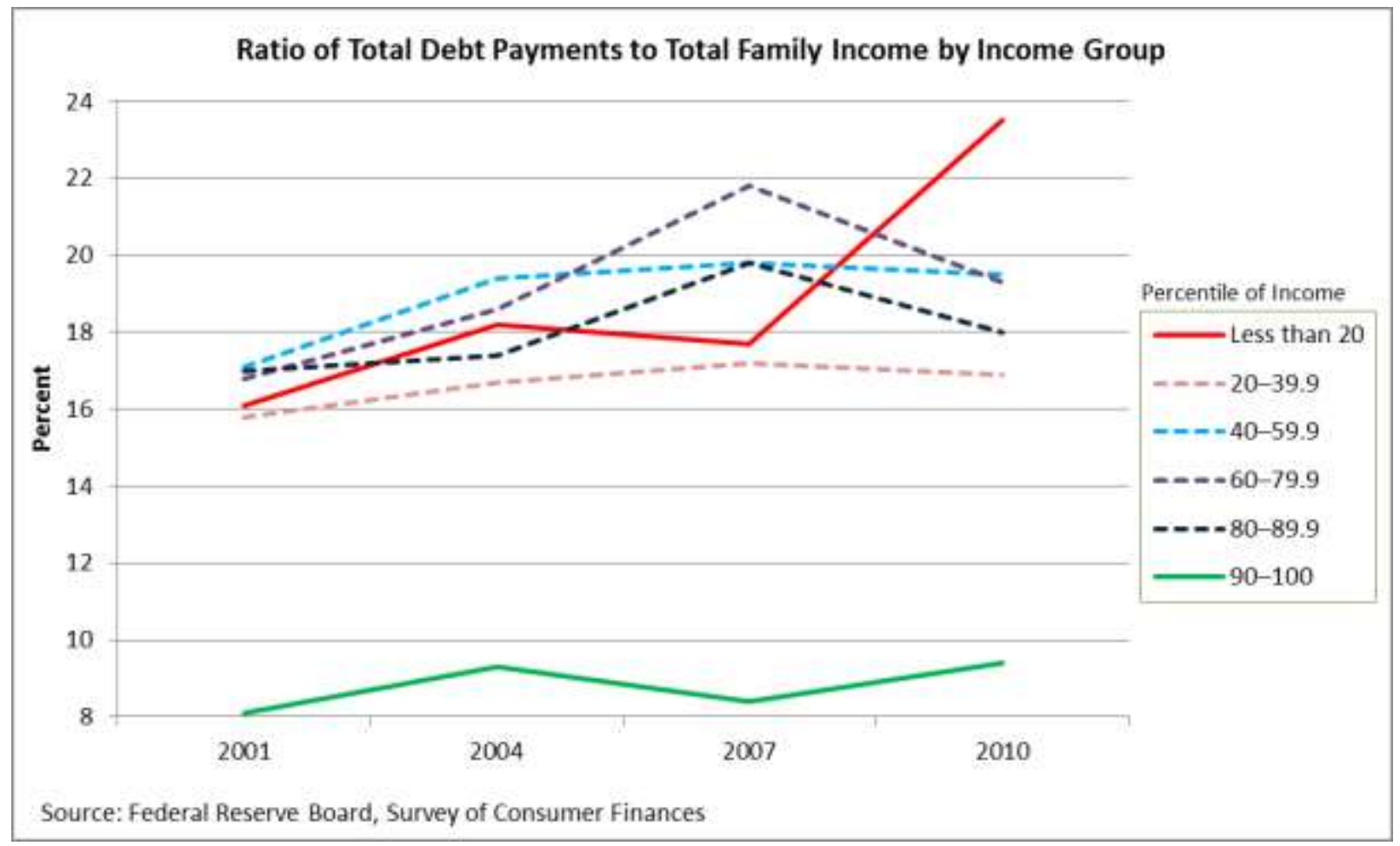

Another way to measure household debt burdens is by reference to leverage ratios - the sum of the debts families owe to the sum of their assets. Pre-recession leverage ratios tell a similar story to that told above, with middle income groups ratcheting up their leverage in the run-up to 2007, while those in the bottom $40 \%$ and top $10 \%$ reduced their leverage. That is the message of Figure 3.

Figure 3

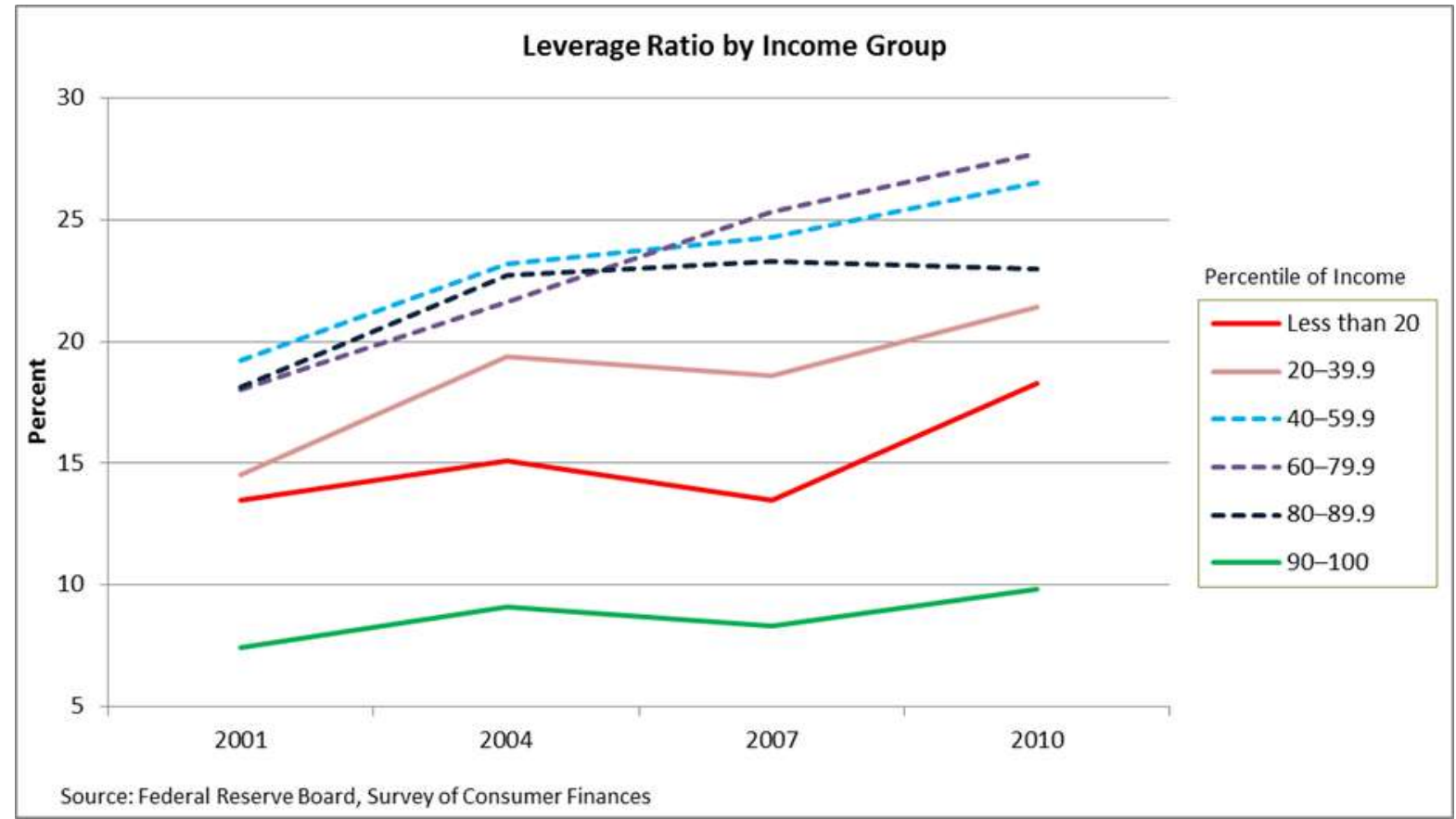


Finally, to disaggregate along another dimension - that of what the debt finances rather than who incurs the debt - we see that mortgage debt in particular skyrocketed in the immediate run-up to our most recent bust and recession. Figures 4 and 5 provide a nice snapshot, the first in nominal terms, the other vis-a-vis GDP.

Figure 4

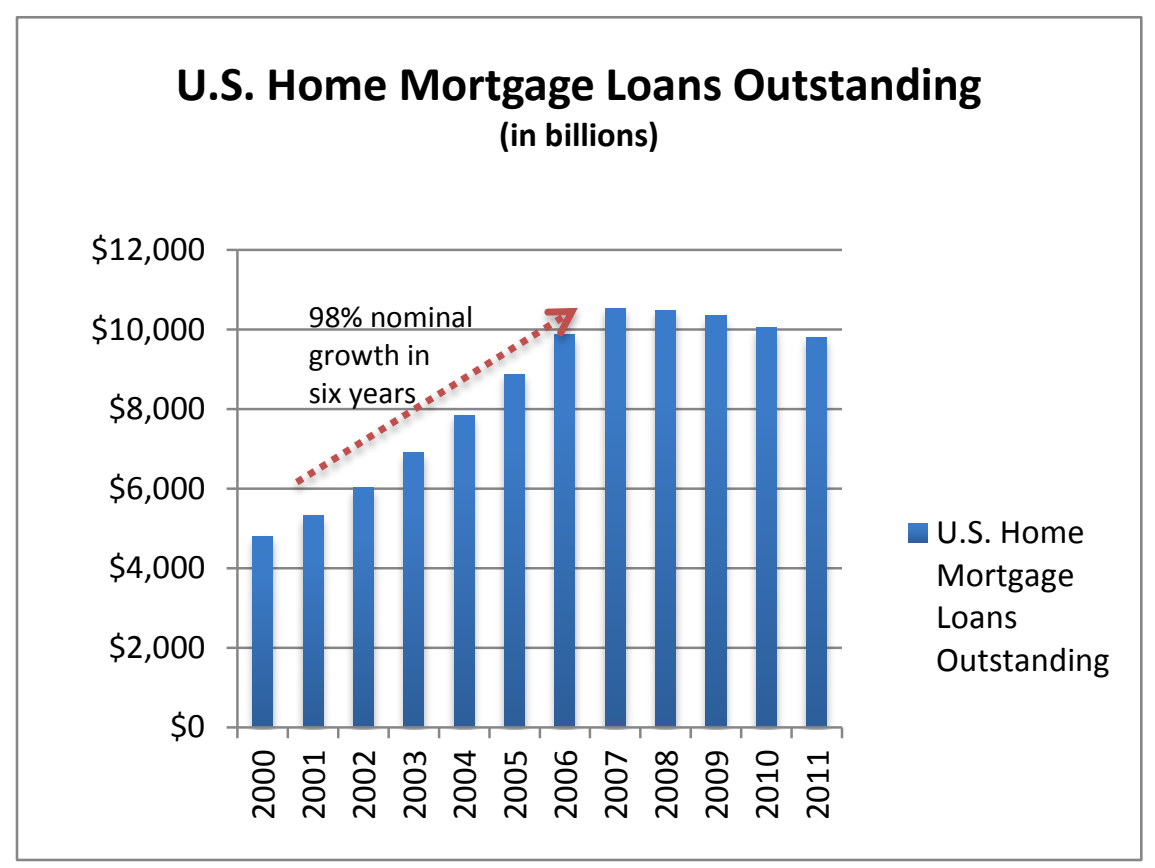


Figure 5

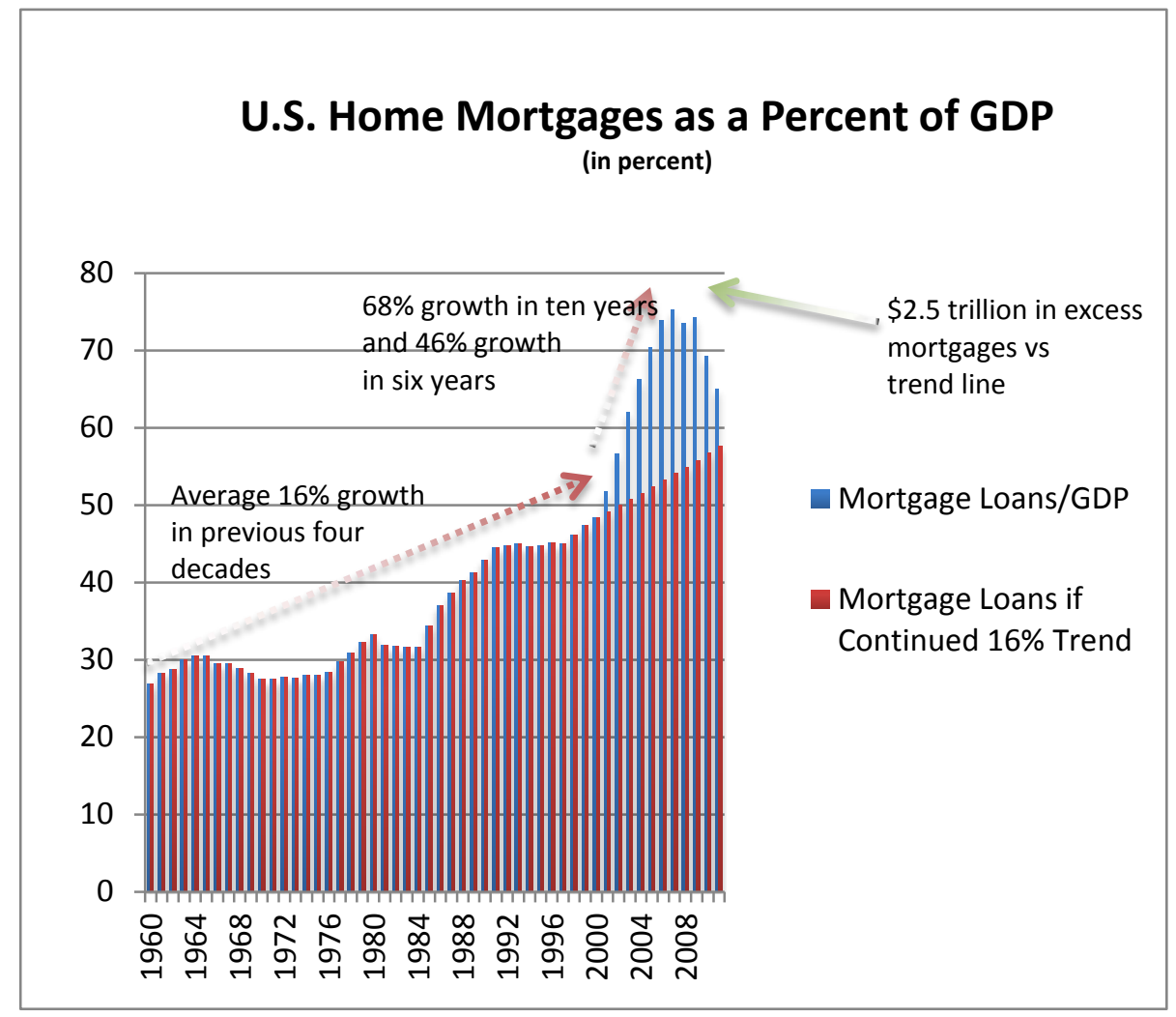

In sum, then, the lead-up to the Great Recession saw the vast majority of Americans - the "great middle" - pile on more debt, most of it taking the form of consumer and mortgage loans. The only people who did not do so were our top and bottom earners. Those at the top were, in effect, the lenders while those in the great middle were their borrowers, while those at the bottom were less likely to purchase homes, hence less likely to assume debt. Since the collapse of 2007-08, by contrast, those in the bottom quintile have joined those in the middle in answering for market fallout, with climbing DTI ratios reflecting their vulnerability to the wider, more radial ravages of debt-deflation and slump.

Complementing the rise in consumer and mortgage debt during the run-up to 2008, of course, was a rise in the issuance of innovative financial instruments facilitating that buildup. These are, in effect, the balance sheet's asset side complements to the debt side buildup just illustrated. Figure 6 shows the issuance trend line for a number of mortgage-backed and associated financial instruments during the first decade of the new millennium. Figure 7 then breaks things down further, showing the composition of new issuances represented by, e.g., mortgage-, student loan-, credit card receivables-, and auto loan-backed securities. 
Figure 6

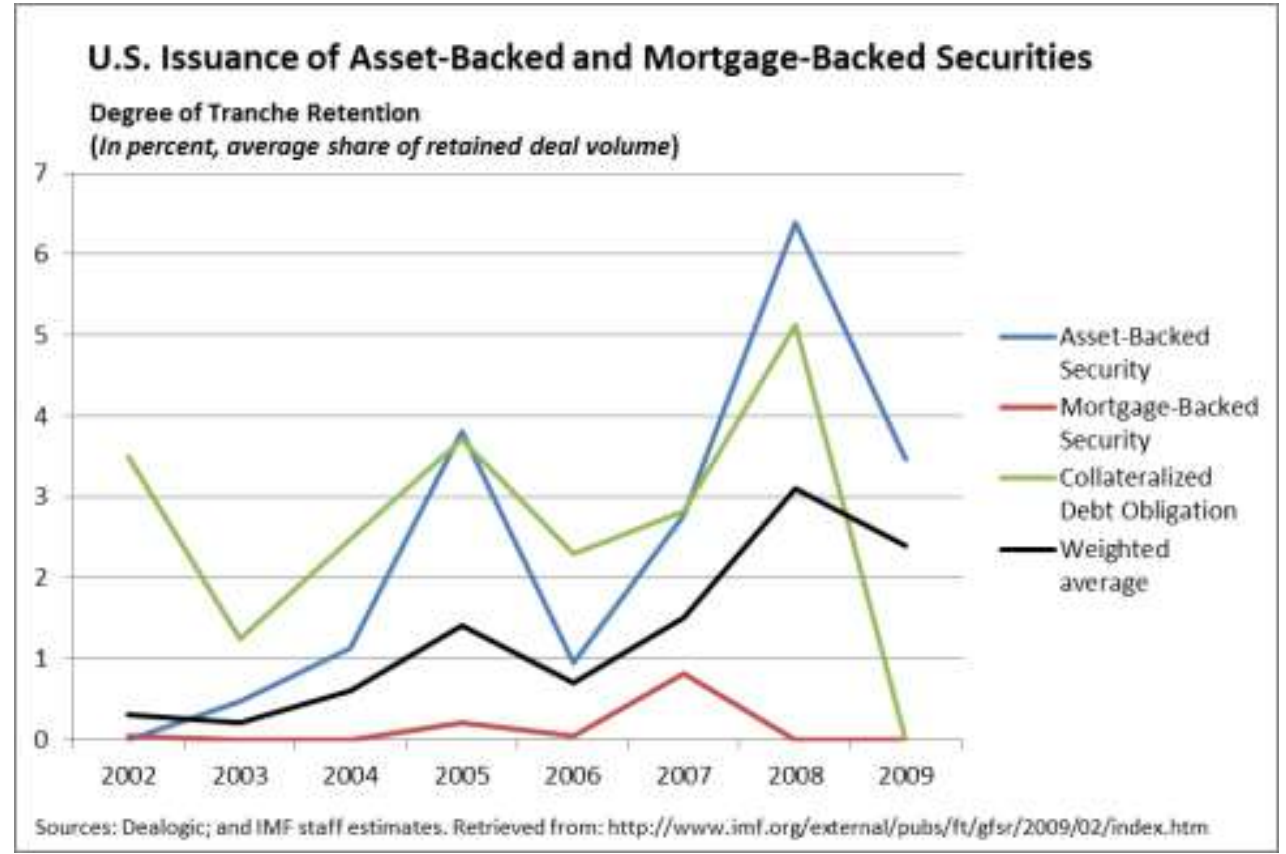

Figure 7

Issuance of Asset-Backed Securities

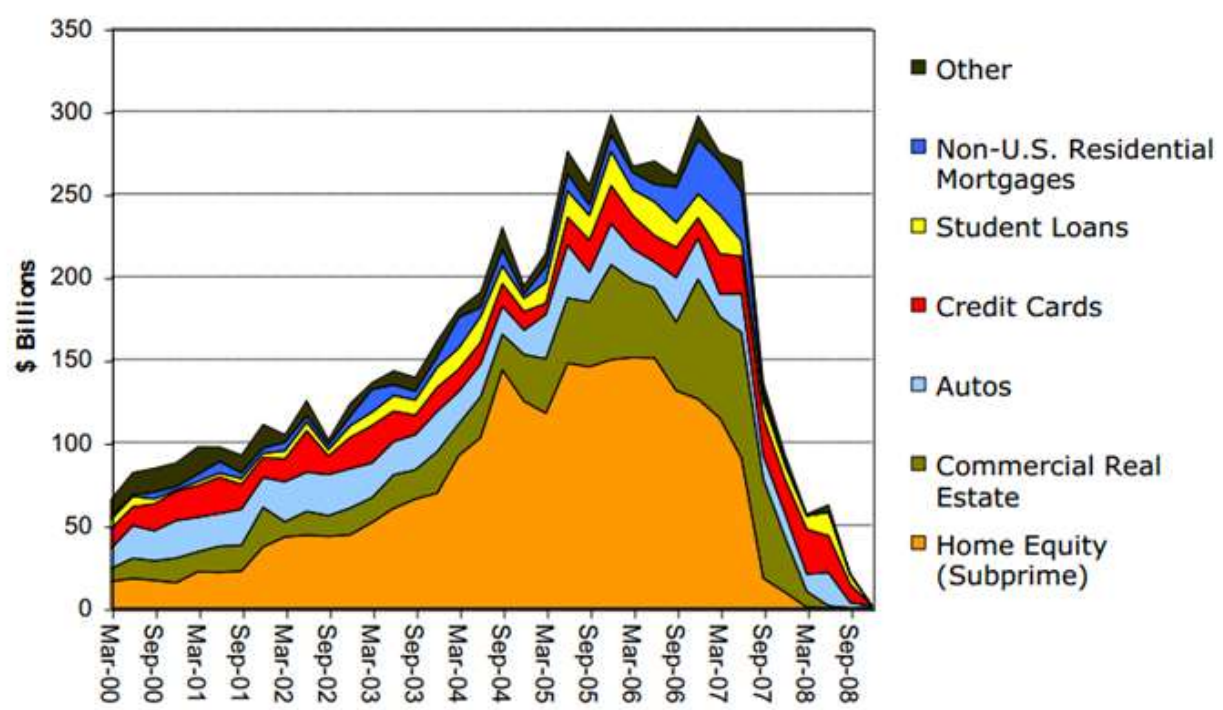

Note: From "The Shadow Banking System: Implications for Financial Regulation" by Tobias Adrian and Hyun Song Shin, July 2009, Federal Reserve Bank of New York, Staff Reports, no. 382. http://www.newvorkfed.org/research/staff reports/sr382.pdf Reproduced with permission. 
Let us now turn briefly to the Great Depression era. While available data here is in some cases not quite as rich as that for the Great Recession era, what we do have exhibits the same pattern.

First, then, debt escalation took place during the lead-up to 1929 as it did in the lead-up to 2008. Initially stoked by an explosion in post First World War U.S. production of mass-market consumer goods, millions of Americans turned to purchasing durables on innovative new time payment arrangements. ${ }^{24}$ Corresponding to latter-day private label securitizations of mortgage debt and credit card receivables, the great financial innovation of the 1920s was the consumer installment plan. Emerging first in the form of auto loans, consumer installment plans eventually facilitated a remarkable 90 percent of major durable goods credit-purchases by the end of the decade. ${ }^{25}$

Consumer debt as a percentage of personal income accordingly doubled from 4.5 percent in 1920 to more than 9 percent in $1929 .{ }^{26}$ A measure of individual and noncorporate debt from the U.S. Commerce Department also reveals that the ratio of individual debt to GDP rose from 55 percent in 1920 to 97 percent in $1932 .{ }^{27}$ A similar trend occurred in respect of home mortgage lending, where "securitization, a reduction in lending standards, and weaker supervision" drove a 1920s real estate boom that took off in 1921 and then began to backsliding in late 1926, doubtless feeding into the stock market volatility that then began to plague the late $1920 \mathrm{~s}^{28} \mathrm{~A}$ simple graphic will once again sum up the trends. Figure 8 shows nominal private debt totals in the years between the end of the First World War and the early years of the Great Depression.

24 Lears, "The American Way of Debt," New York Times, Magazine, June 11, 2006, available at <http://www.nytimes.com/2006/06/11/magazine/11wwln lede.html?pagewanted=all>. Also Hockett, "A FixerUpper for Finance," supra note 2.

25 Murphy, "The Advertising of Installment Plans," Essays in History, Corcoran Department of History at the University of Virginia, at http://etext.virginia.edu/journals/EH/EH37/Murphy.html. Also Hockett, "A Fixer-Upper for Finance," supra note 2.

26 Eichengreen \& Mitchener, "The Great Depression as a credit boom gone wrong," BIS Working Paper 137, Monetary and Economic Dept, September 2003, at 36. Also Hockett, "A Fixer-Upper for Finance," supra note 2.

27 Beim, "It's All About Debt," Forbes, March 19, 2009, available at $<$ http://www.forbes.com/2009/03/19/household-debt-gdp-markets-beim.html>.

See Hockett, "A Fixer-Upper for Finance," supra note 2; also White, "Lessons from the Great American Real Estate Boom and Bust of the 1920s," NBER Working Paper 15573, December 2009, available at <http://www.clevelandfed.org/research/seminars/2010/white.pdf>; and "The Forgotten Real Estate Boom of the 1920s" Harvard Business School, Historical Collections, Accessed June 18, 2012, at <http://www.library.hbs.edu/hc/crises/forgotten.html>. Also Hockett, "Bailouts, Buy-Ins, and Ballyhoo," supra note 2; and Hockett "A Jeffersonian Republic by Hamiltonian Means," 79 S. California Law Review 45 (2006), at http://papers.ssrn.com/sol3/papers.cfm?abstract id=926409. 


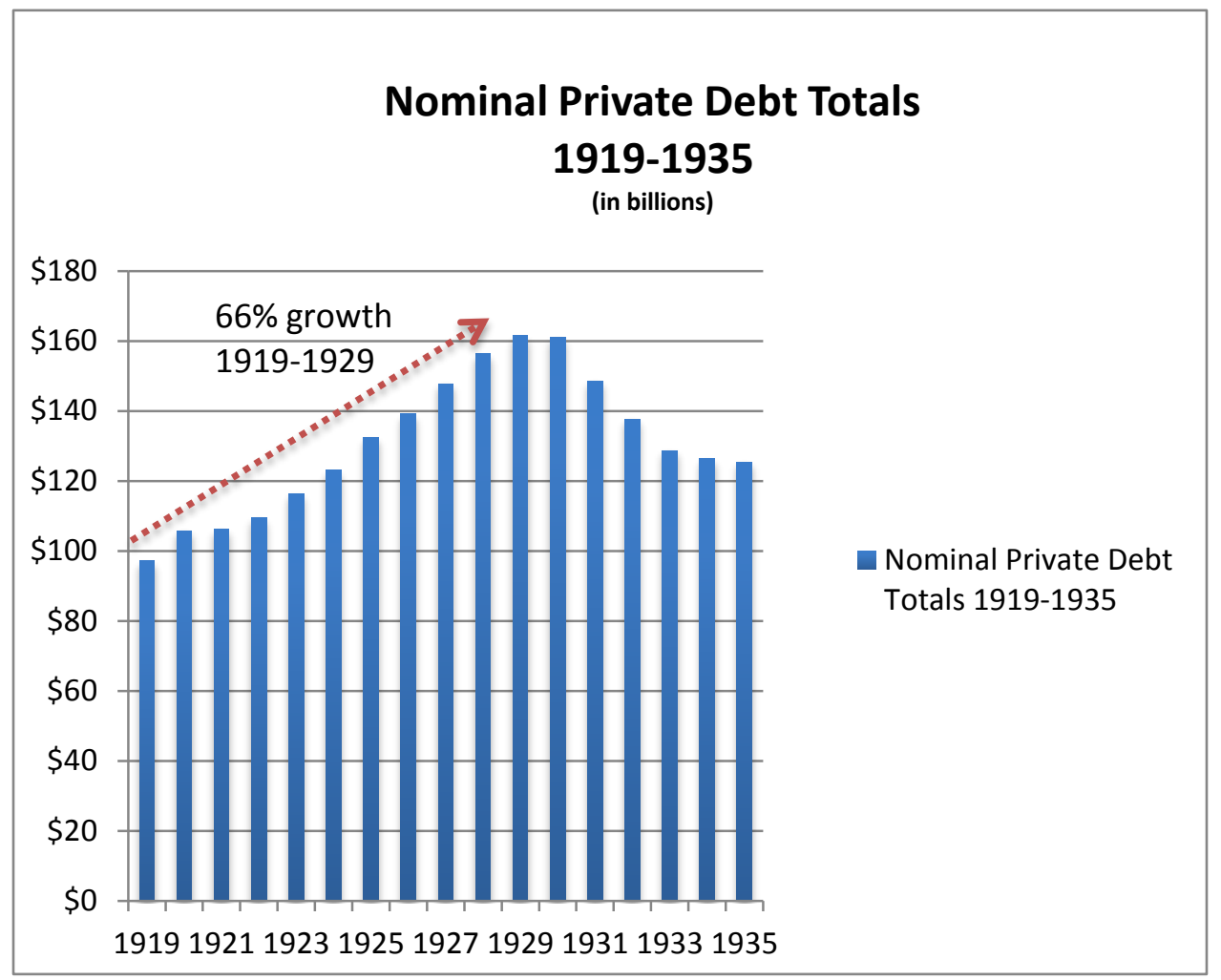

We can now sum up the foregoing with a few more figures and graphics that deal in yet larger aggregates, then look at the behavior of credit-fueled asset prices. In light of the dynamic we sketched in Part 2.A, we would expect to find several more developments in the lead-ups to "great" crashes and slumps like those of the 1920s-30s and the 1990s-2000s. One would be rising private debt aggregates in relation to national income. Another would be widening spreads between asset prices on the one hand, and any "fundamentals" that might justify asset price rises as anything other than "artificially" creditdriven on the other hand. As it happens, we find both in the run-ups to 1929 and to 2008.

To begin with aggregate private-debt-to-GDP trends, Figures 9 and 10 show precisely what our model would lead us to predict. Figure 8 first shows the trend lines prior to the Great Depression and Great Recession. The matchup strikes us as remarkable. 


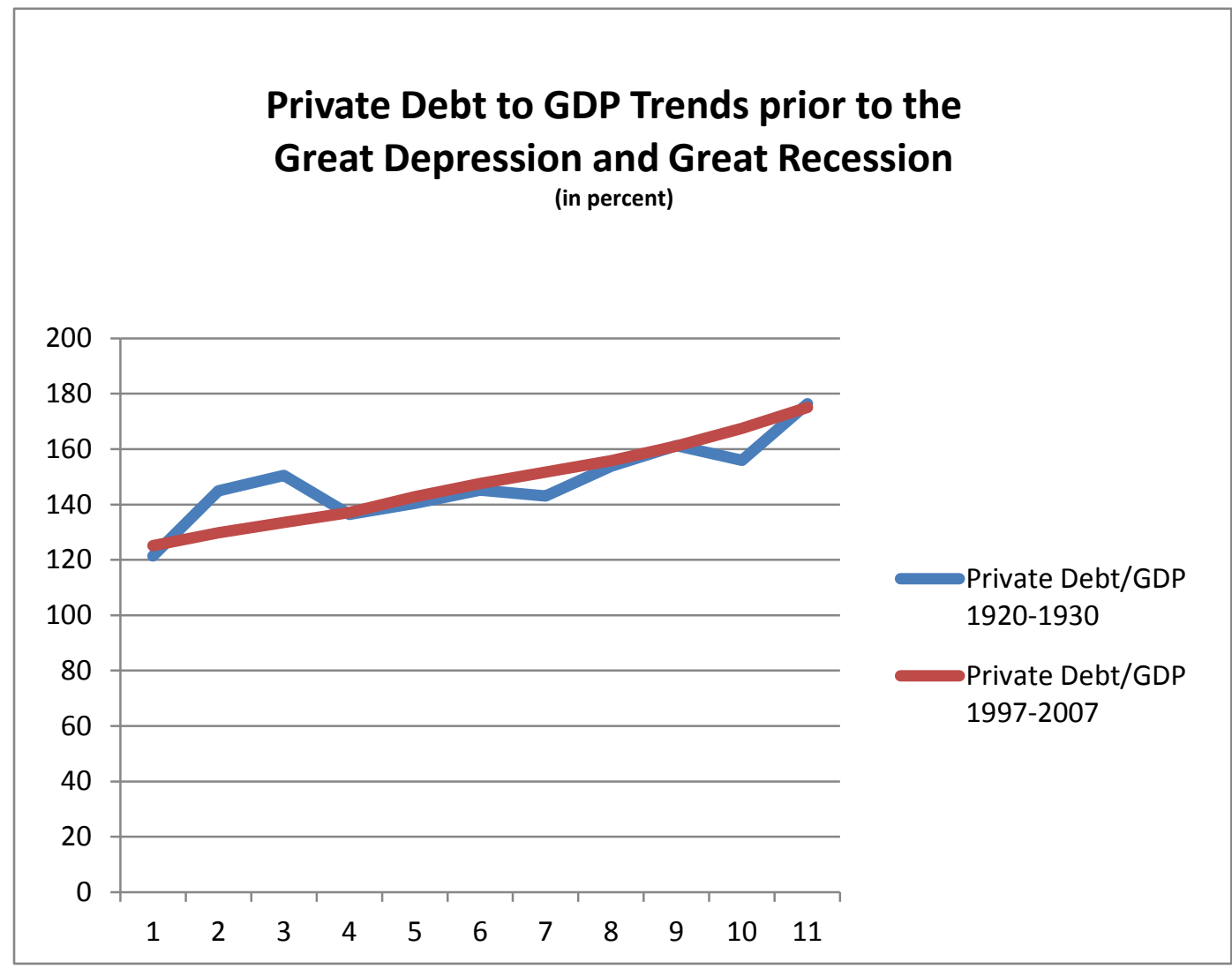

Widening the lens to embrace the entire period from 1916 to 2011 - all years for which data is available - we find the matchup more significant still. For now we find that there is only one other comparable period in which private debt-to-GDP growth was over 40 percent - the period immediately following the Second World War, which on reflection is hardly surprising: At this point the massive de-levering of the Great Depression and War years had left private debt totals at a century-long low. Meanwhile, pent-up demand now had new outlets in goods and appliances produced by factories that were rapidly shifting from wartime to peacetime production - and was boosted yet further, of course, by the Baby Boom. Loan growth, moreover, was facilitated by new federal programs like the GI Bill. So in fact there are only two periods where loan-to-GDP growth is this rapid and private debt to GDP is over 150 percent - again, the 1920 s and the 2000 s. $^{29}$

29

Of the two factors - growth rate of debt vs. the absolute level of debt - rapid growth appears to be the more important factor signaling a potential economic crisis. It is not hard to see why. Very rapid growth in debt is more likely associated with speculative bubble activity than with prudent investment activity. Even apart from that, it can readily result in less speculative but still significant overbuilding or overinvestment in some asset, whether housing, commercial office buildings, stocks and bonds, plants, or something else. After all, population growth was 16 percent compared to 45 percent private debt growth from 1920 to 1930, and 10 percent compared to 41 percent private loan growth from 1997 to 2007. See Clemons \& Vague, supra note 1. 


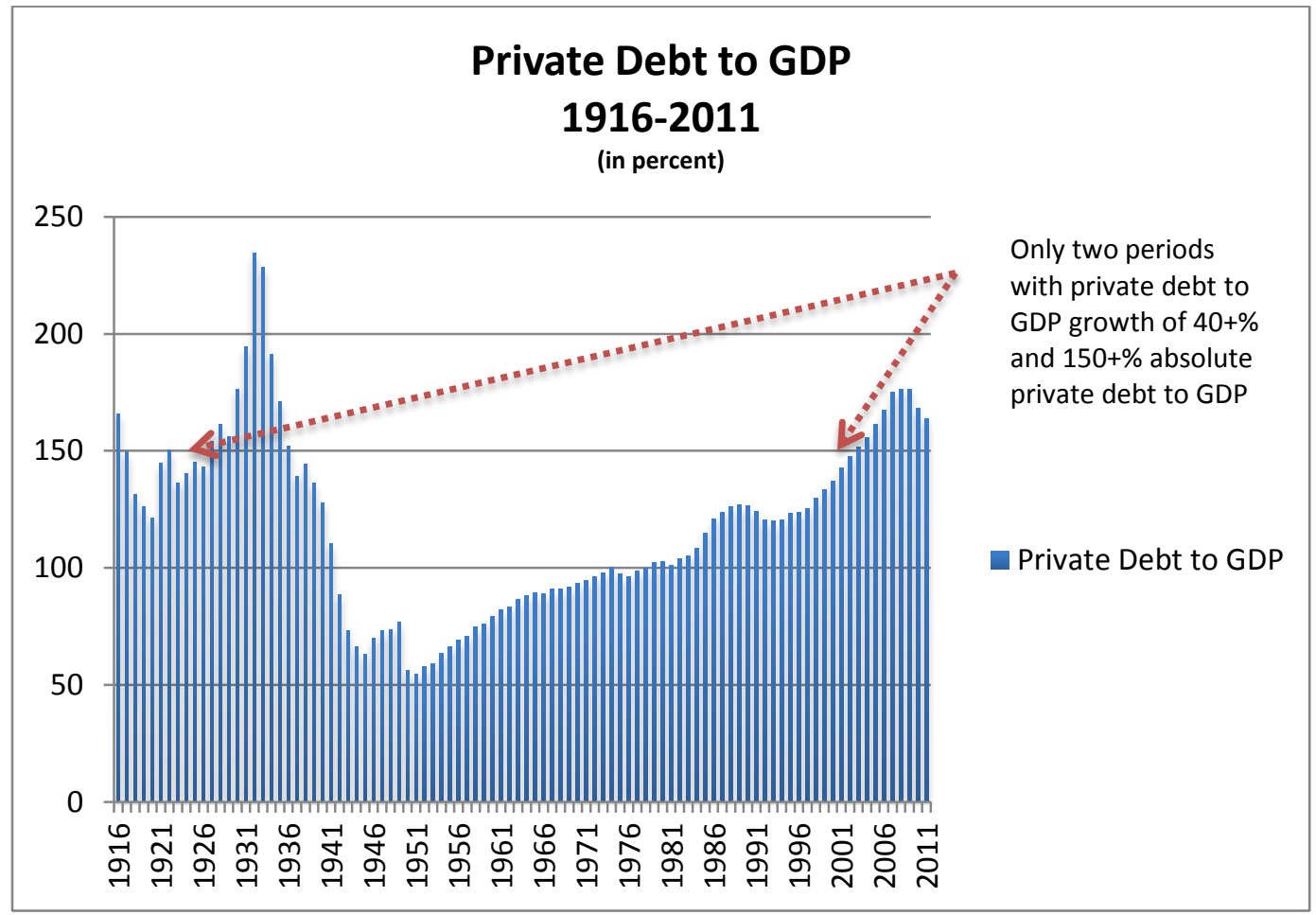

It should also be noted here, given our thesis, that public debt was significantly less than total private debt, and growing far less rapidly, in both pre-crisis periods to which we attend. In fact, as Figure 11 demonstrates, government debt-to-GDP was even declining slightly before 1929. Generally, government debt has been a smaller factor in all but the World War II period. This seems to us significant in light of our claim that the present policy debate focuses improperly on public rather than private debt in explaining the present and previous crises. 
Figure 11

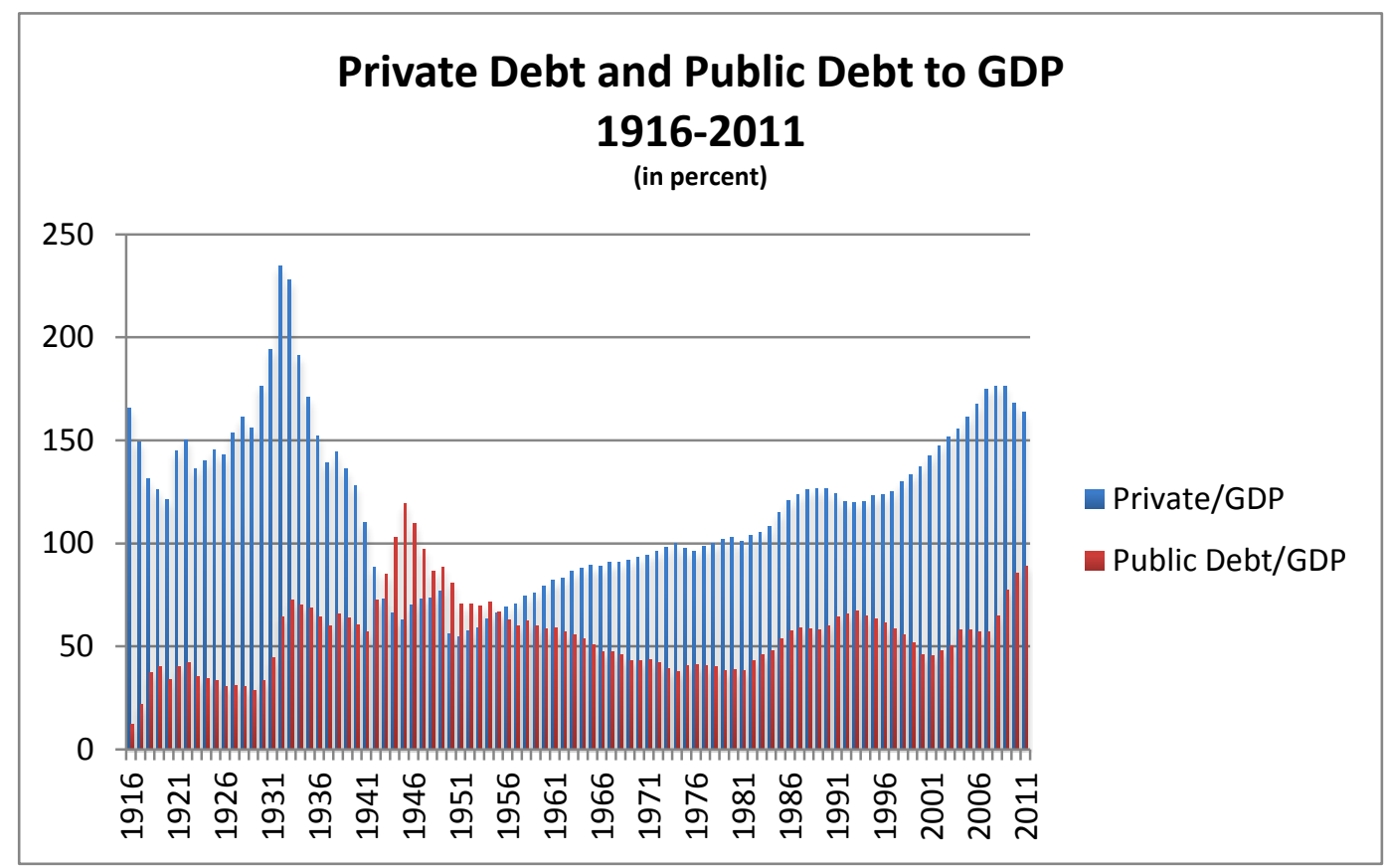

Turning now to spreads between asset prices and plausible underlying "fundamentals," we see that here too what our model would predict is borne out. Figures 12 and 13 track housing and stock prices, respectively, in the lead-up to 2008, plotting each against plausible proxies for sustainable, "fundamental" value: building costs and population in the one case, earnings (via P/Es) in the other. In both cases, the spreads open dramatically over the decade or so leading up to the crash, suggesting that the already-tracked rises in private leverage alone fueled the price rises. 
Figure 12

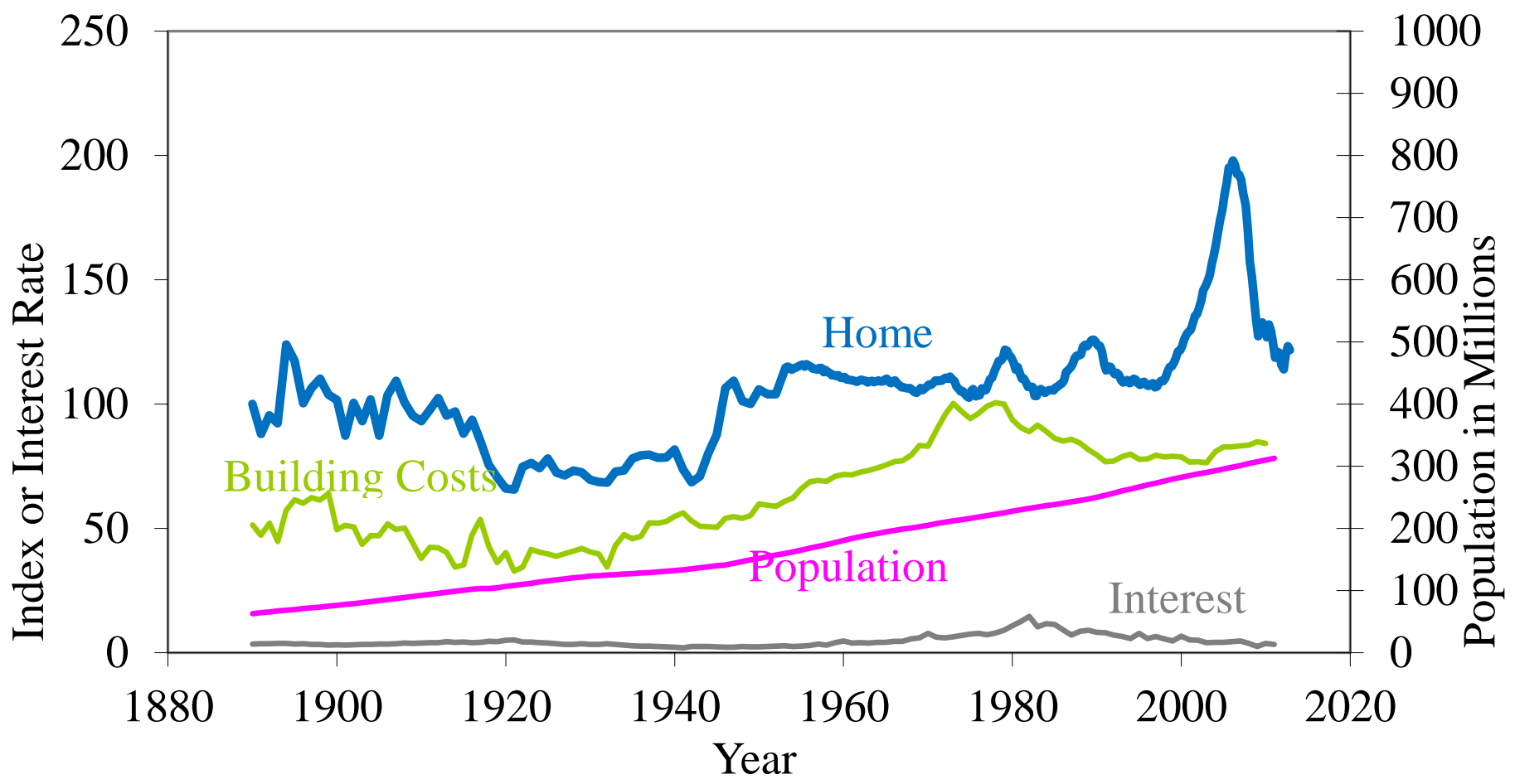

Figure 13

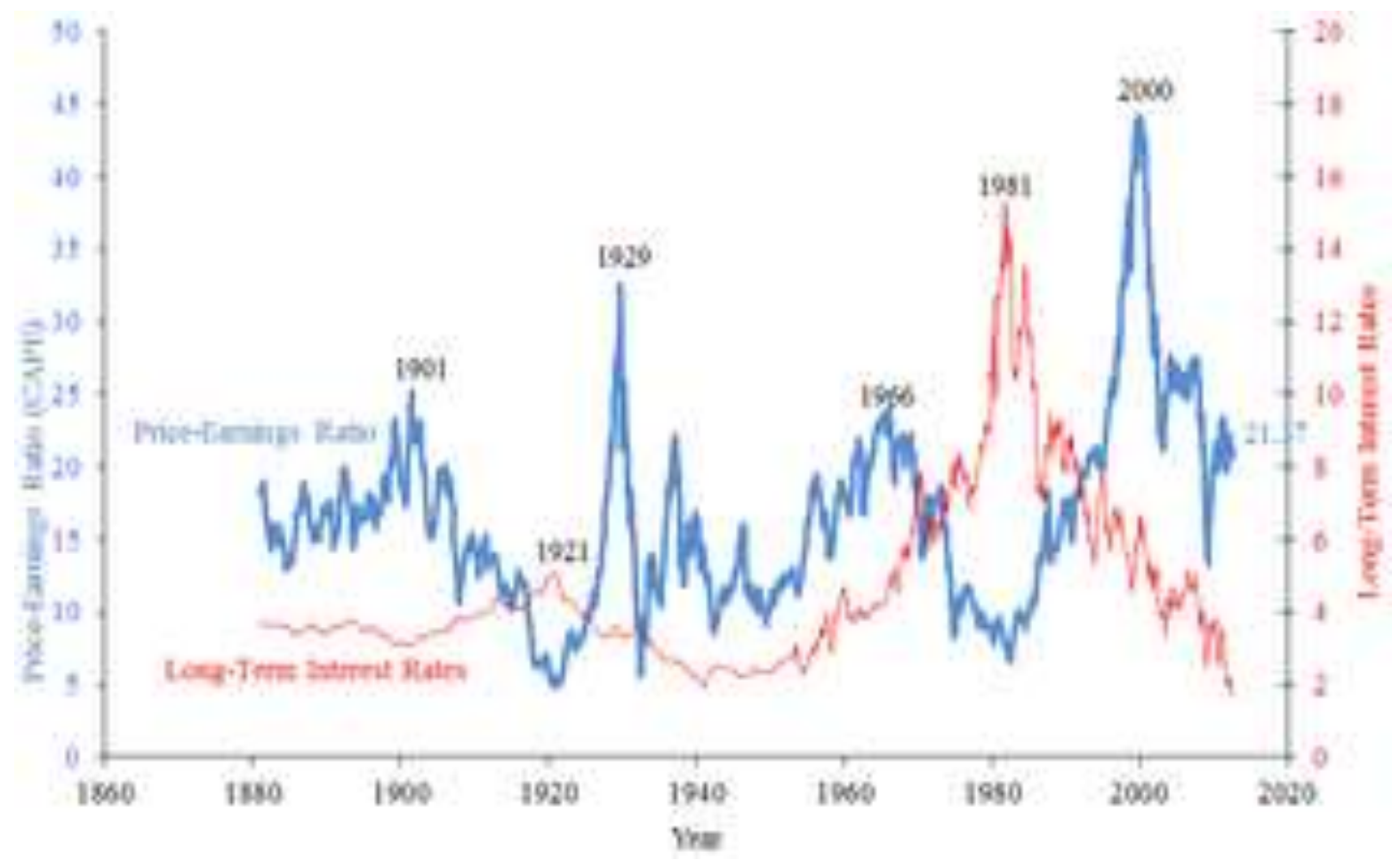


Graphing comparable trend lines for the lead-up to 1929 is somewhat more difficult owing to missing data for many parts of the nation, as well as to papering and collection problems that result in downward biases. What data we have, though, suggests things were much as they were in the lead-up to 2008. A study by Eugene White writing for the National Bureau of Economic Research, for example, suggests that "securitization, a reduction in lending standards, and weaker supervision" drove a 1920s real estate boom that took off in 1921 and then began to backslide around $1926 .{ }^{30}$ Several other assessments likewise confirm a rapid rise in property values as well during the 1920 s - particularly in New York, Florida, and several other localities across the country. ${ }^{31}$

Comparing 1920 and 2000 as baseline years, one study of surges in new residential housing starts during the two periods, controlling for differences in population size, shows an escalation "of the same magnitude" preceding both the Great Depression and Great Recession. ${ }^{32}$ Another survey of several indices left over from the era suggests that real home prices rose anywhere from 20 , to 38 , to 54 percent depending on the index and region. ${ }^{33}$

In Manhattan, home prices continued to rise until the third quarter of 1929 , when they fell off a cliff, plunging 67 percent by the end of $1932 .{ }^{34}$ The residential property foreclosures that first mounted in 1926 continued to climb steadily through the crash of 1929 and didn't slow pace until $1933 .{ }^{35}$ In the five years between 1928 and 1933, nationwide home prices fell nearly 26 percent. ${ }^{36}$ So marked was the adoption of debt and subsequent loss of assets that, quoting a 1932 Harpers article, Jackson Lears writes, "the middle-class homeowner no longer has possessions but only obligations."'37 That reads familiar: It's where we are now.

\footnotetext{
30 See Hockett, "A Fixer-Upper for Finance," supra note 2; also White, "Lessons from the Great American Real Estate Boom and Bust of the 1920s," NBER Working Paper 15573, December 2009, available at <http://www.clevelandfed.org/research/seminars/2010/white.pdf>; and "The Forgotten Real Estate Boom of the 1920s" Harvard Business School, Historical Collections, Accessed June 18, 2012, at <http://www.library.hbs.edu/hc/crises/forgotten.html>. Also Hockett, "Bailouts, Buy-Ins, and Ballyhoo," supra note 2; and Hockett, "A Jeffersonian Republic by Hamiltonian Means," infra note 116.

31 "The Forgotten Real Estate Boom of the 1920s", idem.; White, idem at 3; see also Nicholas \& Scherbina, "Real Estate Prices during the Roaring Twenties and the Great Depression," Harvard Business School, March 21, 2001, available at < http://people.hbs.edu/tnicholas/Anna tom.pdf>; Hockett, "A Fixer-Upper for Finance," supra note 2; Hockett, "Bailouts, Buy-Ins, and Ballyhoo," supra note 2; and Hockett, "Jeffersonian/Hamiltonian," supra note 28 .

32 White, supra note 30 at 6; Hockett, sources cited supra, notes 30, 31.

33 White, supra note 30 at 8, 9; Hockett, sources cited supra, notes 30, 31.

$34 \quad$ Nicholas \& Scherbina, supra note 34; and Hockett, sources cited supra, notes 30, 31.

35 "The Forgotten Real Estate Boom of the 1920s", supra note 30; and Hockett, sources cited supra, notes $30,31$.

36 See Curnutte, "Home Value Declines Surpass Those of Great Depression," Zillow, January 11, 2011, available at <http://www.zillow.com/blog/2011-01-11/home-value-declines-surpass-those-of-great-depression/>.

37 See Lears, "The American Way of Debt," New York Times Magazine, June 11, 2006, available at <http://www.nytimes.com/2006/06/11/magazine/11wwln lede.html?pagewanted=all>. Also Hockett, "A FixerUpper for Finance," supra note 2.
} 


\section{Where We Are Now}

What goes up, must come down. At least this is so when the "up" has been too high. The come-down has happened in the case of many assets purchased on credit during the bubble period most notably housing, by far the largest determinant of net worth on the asset side of middle class balance sheets, hence the asset whose value bears most on consumer spending. It has not happened, however, in the case of the debt incurred during the bubble years to purchase those assets - especially, once again, mortgage debt. A few numbers and graphics will once again give us some appreciation of the measure of the problem. That in turn will both (a) make clear why we are where we are, and (b) hint strongly at what we must do to get out of here.

\section{A. Mortgage Debt Overhang}

To begin with housing, at the time of the plunge seven years ago, prices dropped nationally by $35 \%$, wiping out over $\$ 7$ trillion in home equity. Prices still linger near $30 \%$ below peak levels, which is likely inflated for reasons to which we'll return. ${ }^{38}$ In harder hit communities the figure is much greater well over $50 \%$ in the proverbial "sun and sand" states, to which we'll return. ${ }^{39}$ This remains true notwithstanding cyclical fluctuations pursuant to which prices rise somewhat in some seasons, only to plummet again between peaks. Case-Shiller housing price data compiled since July 2006 in represented in Figure 14, for example, indicate that the highest post-bubble price-peak prior to the past summer came, not last year or the year before that, but in August of 2009, while early 2012 for its part saw the deepest post-bubble trough since January 2009. Many analysts, then, not surprisingly predict more price retreats ahead. ${ }^{40}$

38 See latest data compiled by CoreLogic, available at http://www.corelogic.com/; and OcC Mortgage Metrics, available at http://www.occ.treas.gov/publications/publications-by-type/other-publicationsreports/index-mortgage-metrics.html. Some of what follows draws on Hockett, "It Takes a Village," supra note 2; and Hockett, "Paying Paul," supra note 2.

39 Idem. See also state and local data provided infra.

40 See, e.g., See Testimony of Laurie S. Goodman, Amherst Securities Group, to the U.S. Senate Subcommittee on Housing, Transportation, and Community Development, March 15, 2012, available at http://banking.senate.gov/public/index.cfm?FuseAction=Files.View\&FileStore id=0f96e0ff-8500-41a5-a0f20139d0df2e07; Diana Olick, “Is Housing Recovering as Much as Everyone Thinks?,” Realty Check, 9 October 2012, available at http://www.cnbc.com/id/49343717/Is Housing Recovering as Much as Everyone Thinks (citing Laurie Goodman, among others); and Ritholtz, "Fascinating Mortgage and Housing Data Points," June 17, 2012 (reporting on Goodman numbers), available at http://www.ritholtz.com/blog/2012/06/fascinating-mortgagehousing-data-points/. See also Goodman et al., Amherst Mortgage Insight: Non-Agency MBS - Decomposing the Returns, September 27, 2012. 
Figure 14

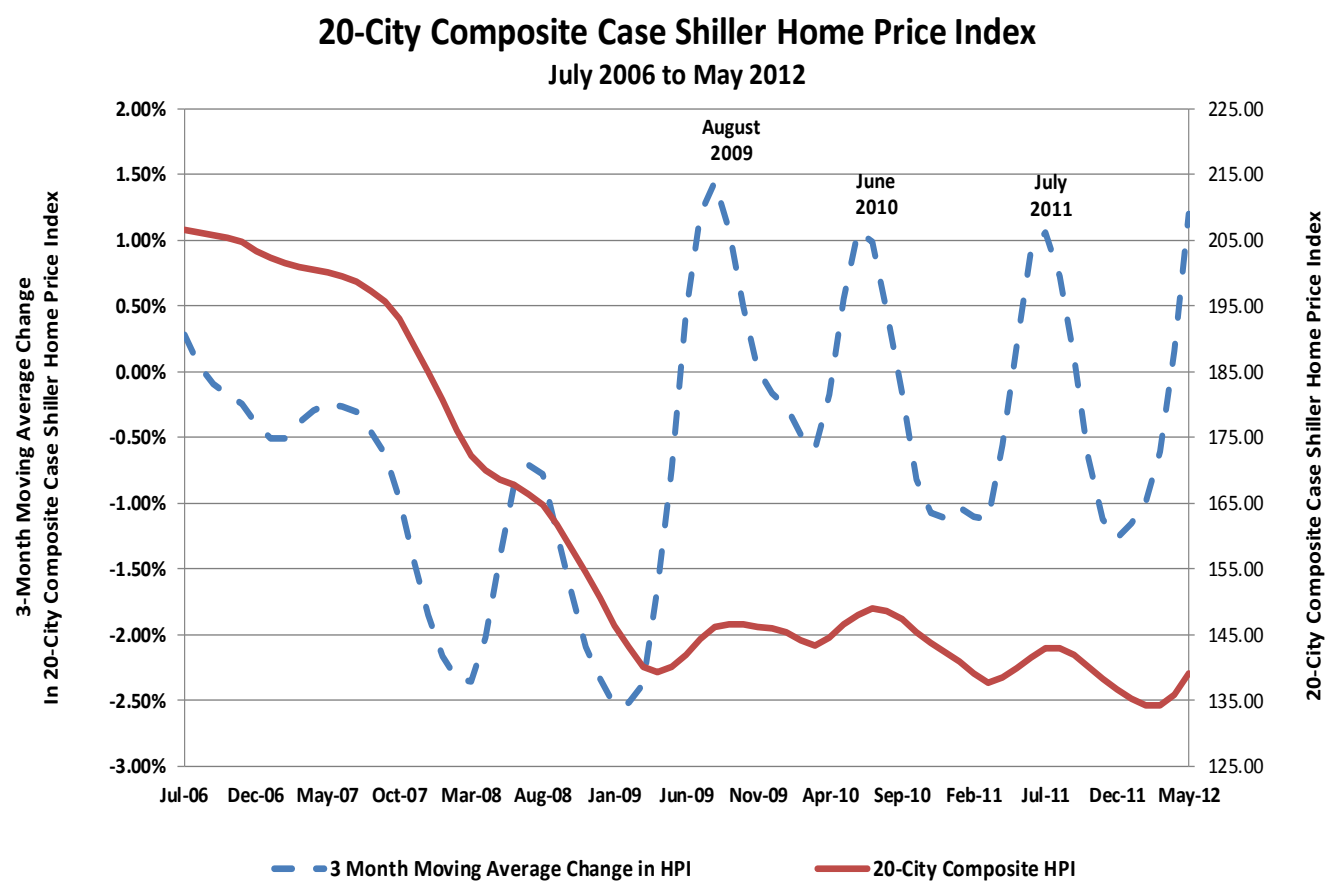

Mortgage debt levels, troublingly, have not dropped in a manner commensurate with home prices. In consequence well over 11 million homes are now underwater. ${ }^{41}$ That is nearly a quarter of all American homes with mortgages outstanding. ${ }^{42}$ These underwater loans tend, if not modified, to default at high rates. Expected default rates are as high as $75 \%$, for example, for loans that are $40 \%$ or underwater - that is, with LTVs of $140 \% .{ }^{43}$ GSE filings with the SEC, by way of additional example, provide more telling numbers: for 2006 vintage loans, $71 \%$ of subprimes, $70 \%$ of option ARMs, $58 \%$ of variable rate loans, and $40 \%$ even of fixed rate loans are expected to default. ${ }^{44}$

In this light it is perhaps not surprising that of the 11 million mortgaged homes just mentioned, upwards of 4 million are already in default, in foreclosure, or foreclosed and awaiting liquidation. ${ }^{45}$ Over 2 million more are "seriously" delinquent - two-to-four payments in arrears. ${ }^{46}$ This in turn means that fewer than half of our over 11 million underwater home mortgage loans are now current, ${ }^{47}$ and more go delinquent each month: ${ }^{48}$ Together with loans that are already defaulted or delinquent, most housing

\footnotetext{
$41 \quad$ See sources cited supra, note 40.

42 Idem.

43 See http://www.proteckservices.com/hvf-lessons-from-the-data/negative-equity-stage-one-of-distressedreal-estate-inventory/.

44 See FNMA's second quarter 2012 Form 10-Q, page 111, available at

http://www.fanniemae.com/resources/file/ir/pdf/quarterly-annual-results/2012/q22012.pdf. Also its 2011 Form 10-K data, available at http://www.fanniemae.com/resources/file/ir/pdf/quarterly-annualresults/2011/10k 2011.pdf.

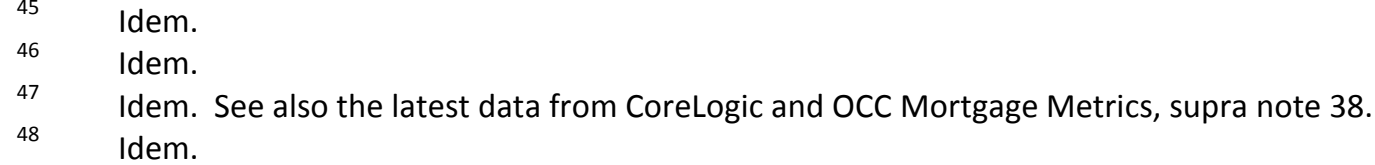


analysts expect between 7.5 million and 9.5 million additional homes to go into liquidation over the next several years absent serious remedial action. ${ }^{49}$ This would be into an already depressed market, ${ }^{50}$ and would mean a backlog totaling to approximately $200 \%$ of annual existing home sales in the U.S. at current sales paces. ${ }^{51}$

Even these figures understate things in significant ways. For one thing, Federal Reserve policy since the crash has been to place a bottom under real estate prices via purchases of real-estateassociated financial assets - notably through the New York Fed's Maiden Lane Funds and the Open Market Committee's QE3 commitments. For another thing, many banks appear to be both forbearing on foreclosure and forestalling on loss-accounting, both to avoid public damage to balance sheets and, for a while, for fear after the "robo-signing" scandals of 2010. Finally, as mentioned before, the negative equity problem is especially concentrated in some areas in a manner that aggregate national numbers obscure. That is important because, owing to symbiotic "feedback" effects between foreclosure, surrounding property values, local tax revenue and services, and local consumer spending patterns, concentrated negative equity is more harmful than thinly spread negative equity for a given aggregate.

A few numbers and figures are once again telling. With respect to concentration, there are some communities in which more than $80 \%$ of private label securitized (PLS) mortgage loans, which account for the bulk of problem loans, are underwater. In some of these, moreover, the degree to which the affected loans are underwater is remarkable: there are communities whose underwater PLS loans have average loan to value (LTV) ratios greater than $200 \%$. Figure 15 affords a revealing, if nevertheless understated, ${ }^{52}$ summary overview of how localized the worst of the nation's underwater mortgage loan problem actually is: ${ }^{53}$

\footnotetext{
$49 \quad$ See, e.g., Fannie and Freddie 10K data cited below. See sources cited supra, note 40. Idem. The chart covers all underwater loans, hence does not reflect distinctions between high LTV and lower LTV such loans.

53 Source is CoreLogic, Negative Equity Report, $4^{\text {th }}$ Quarter 2012, available at http://www.corelogic.com/.
} 
Figure 15

UNDER-EQUITY AND NEGATIVE EQUITY SHARE COMBINED BY COUNTY

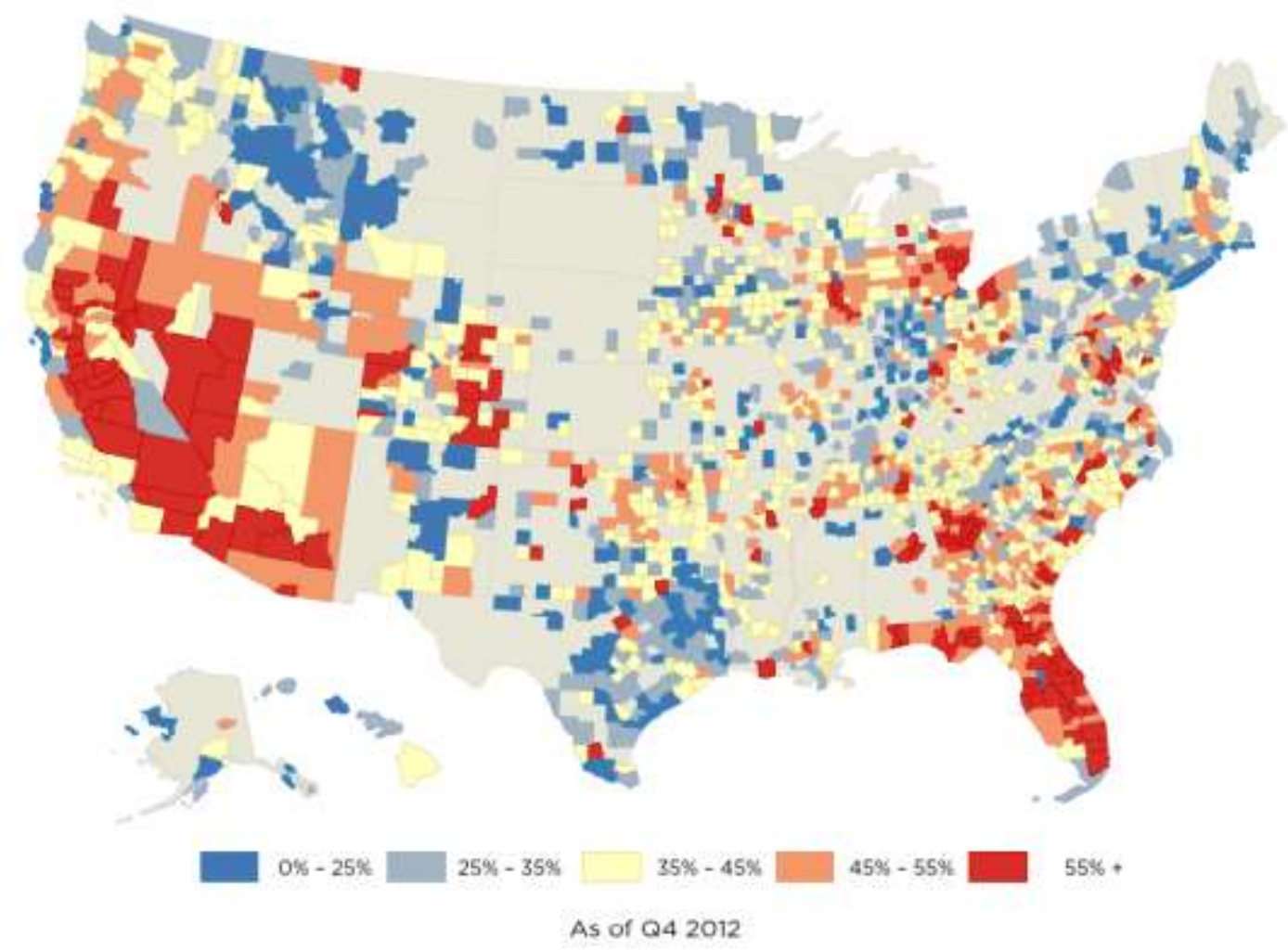

Negative equity and associated default rates of such magnitude are subject to mutuallyreinforcing feedback dynamics of the kind found in our model described in Part II. Foreclosures and consequent slump in local housing markets feed back into local economies, hence ultimately the national economy, by diminishing wealth and consumer spending. ${ }^{54}$ (Negative equity is estimated to have cost the American economy $\$ 90$ billion per year in lost disposable income. ${ }^{55}$ ) That in turn lowers both growth and employment - bad enough in themselves, but also drawing more mortgage loans into the wave of delinquency and default. ${ }^{56}$ Hence the familiar self-worsening "downward spiral" at worst, or "holding pattern" at best, of high underwater loan and foreclosure rates, causing low growth and employment, causing yet more default and foreclosure, and so on. ${ }^{57}$

54 See, e.g., Federal Reserve Board, The U.S. Housing Market: Current Conditions and Policy Considerations, White Paper, January 4, 2012, at 3. Also William C. Dudley, "Housing and the Economic Recovery," Remarks at the New Jersey Bankers Association Economic Forum, January 6, 2012, available at http://www.newyorkfed.org/newsevents/speeches/2012/dud120106.html.

See Boyce, Absalon Project, "Streamlined Refinance and Other Ideas to Improve the Mortgage Market," (Oct. 2010), page 8 http://absalonproject.com/wp-content/uploads/2010/11/Streamlined-Refinance-and-OtherIdeas.pdf .

Idem. Also Hockett, "It Takes a Village," supra note 2; Hockett, "Paying Paul," supra note 2; and Hockett, "Six Years On and Still Counting: Sifting Through the Mortgage Mess," 9 Hastings Business Law Journal 1 (2013), available at http://papers.ssrn.com/sol3/papers.cfm?abstract id=2029262.

$57 \quad$ Idem. Also Hockett, "Recursive Collective Action Problems," supra note 7. Note also that even the dismal consumer spending and growth numbers we have are skewed upward in owing to the "shadow stimulus" entailed 
We can see this dynamic at work very clearly by concentrating attention on two sample counties in two states that (a) appear to have been targeted with particular intensity by subprime lenders eager to service the investment demands of parties at the top of the wealth distribution during the bubble years, and (b) have suffered accordingly since the bubble's burst. We refer to San Bernardino in California and Wayne County in Michigan.

In California, the figure is approximately 2 million underwater homes, representing about $29 \%$ of the total statewide, ${ }^{58}$ while in San Bernardino County the figure is over 168,000 homes, representing more than $43 \%$ of the total countywide. ${ }^{59}$ In both cases, housing prices are down well over $40 \%$ from their 2006 peaks - 44\% for California, 51\% for the Riverside-San Bernardino-Ontario area ${ }^{60}$ - while the average LTV on San Bernardino's underwater mortgage loans is nearly $170 \% .{ }^{61}$ Unsurprisingly, then, San Bernardino has significantly higher unemployment and poverty rates even than does the nation at large. Its unemployment rate stands at $11.9 \%$ as compared to a national figure of $7.9 \%,{ }^{62}$ while its poverty rate stands at $19.3 \%$ as compared to a national figure of $15.9 \%{ }^{63}$

In Wayne County, Michigan - the county in which Detroit is located - the figures are again telling. Approximately 450,000 homes, representing a remarkable $33 \%$ of the total statewide, are underwater in Michigan. ${ }^{64}$ Home prices statewide are down 25\% from their 2006 peak, while in Wayne County's Detroit-Livonia-Dearborn area the figure is $38 \% .{ }^{65}$ As with San Bernardino, California, then, so

by the 24 to 36 months necessary to complete foreclosure and eviction in connection with defaulted mortgage loans. For each homeowner who is ultimately evicted, the period in question represents a period free of housing costs - costs which resume after eviction, diverting that much more away from would-be consumer spending. 58 Idem.

59 CoreLogic, Negative Equity Report, $1^{\text {st }}$ Quarter 2012, available at http://www.corelogic.com/. For more on why San Bernardino makes for an illustrative case study, see, e.g., Medina, "In California, Economic Gap of East vs. West," New York Times, April 14, 2012, page 1, available at http://mobile.nytimes.com/article; jsessionid=ADA9B1FACB49BF39B4CF50B58646AFBF. w6 $\mathrm{a} a=938651 \& \mathrm{f}=19$. Data from FHFA, available at

http://www.fhfa.gov/default.aspx?Page=86\&Area=MSA\&AreaID=\&PurchaseQtr=\&ValuationQtr=\&Price=\&nr=1.

61 See www.dqnews.com for State - \$484K in 2007 and \$239K in Feb2012 - and www.City-Data.com for County - approximately \$380K in 2007 and \$155K in 2011.

62 See http://www.washingtonpost.com/wp-srv/special/nation/unemployment-by-county/.

63 For San Bernardino, see

http://factfinder2.census.gov/faces/tableservices/jsf/pages/productview.xhtml?pid=ACS 11 1YR S1701\&prodTyp $\mathrm{e}=$ table. For the U.S., see http://factfinder2.census.gov/faces/tableservices/isf/pages/productview.xhtml?pid=ACS 11 1YR S1701\&prodTyp e=table.

64 See again CoreLogic, Negative Equity Report, $4^{\text {th }}$ Quarter, 2012, supra note 59.

65 See again FHFA data as cited supra, note 60. 
with Wayne County, Michigan: its unemployment rate is $11 \%$ as compared to the nation's $7.9 \%,{ }^{66}$ while its poverty rate is $25 \%$ as compared to the nation's $15.9 \% .{ }^{67}$

The cyclical patterns we noted in respect of the nation at large also carry over to the worst hit localities. Notwithstanding the earlier mentioned periodically transient signs of improvement in aggregate home prices, for example, S\&P Case-Shiller 20 City data has recently shown California and San Bernardino home prices down fully $11 \%$ and $14 \%$, respectively, even from their previous post-bubble highs reached in 2010. ${ }^{68}$ Meanwhile, a backlog of nearly 232,000 homes in California, with 20,000 in San Bernardino alone, and nearly 62,000 homes in Michigan, with 15,000 in Wayne County alone, are now either in default, held in bank real estate owned (REO) portfolios, or up for auction post-foreclosure. ${ }^{69}$ The California figures suggest further deterioration since last year's "shadow inventory" of some 174,000 homes in California and 14,000 homes in San Bernardino County that were then either already foreclosed or on the brink of foreclosure. ${ }^{70}$

A bit more local level data will complete the mortgage debt picture for present purposes. Figure 16 shows percentages of mortgage loans underwater and housing price declines from peak, in percentage terms, for a sampling of zip code areas through the end of $2012:^{71}$

Figure 16

\begin{tabular}{|r|r|r|r|r|}
\hline \multicolumn{1}{|c|}{ ZIP Code } & \multicolumn{1}{|c|}{ City } & \% Underwater & \% Price Decline \\
\hline 92301 & Adelanto & CA & $64 \%$ & $-70 \%$ \\
\hline 93501 & Mojave & CA & $65 \%$ & $-71 \%$ \\
\hline 93505 & California City & CA & $72 \%$ & $-71 \%$ \\
\hline 33035 & Homestead & FL & $68 \%$ & $-69 \%$ \\
\hline 33127 & Miami & FL & $57 \%$ & $-70 \%$ \\
\hline
\end{tabular}

66 See http://www.washingtonpost.com/wp-srv/special/nation/unemployment-by-county/.

67 For Wayne County, see

http://factfinder2.census.gov/faces/tableservices/jsf/pages/productview.xhtml?pid=ACS 11 1YR S1701\&prodTyp $\mathrm{e}=$ table. For the U.S., see again

http://factfinder2.census.gov/faces/tableservices/jsf/pages/productview.xhtml?pid=ACS 11 1YR S1701\&prodTyp $\frac{\mathrm{e}=\text { table. }}{68}$.

See www.dqnews.com for State - \$270K in July 2010 and \$239K in Feb 2012 - and www.City-Data.com approximately \$180K in 2010 and \$155K in 2011.

69 For California and San Bernardino, see RealtyTrac data at http://www.realtytrac.com/trendcenter/default.aspx?address=CA\&parsed=1\&stc=ca and http://www.realtytrac.com/trendcenter/default.aspx?address=San\%20Bernardino\%20county\%2C\%20CA\&parsed= $1 \& \mathrm{cn}=$ san\%20bernardino\%20county\&stc=ca, respectively. For Michigan and Wayne County, see counterpart RealtyTrac data at http://www.realtytrac.com/trendcenter/default.aspx?address=MI\&parsed=1\&stc=mi and http://www.realtytrac.com/trendcenter/default.aspx?address=Wayne\%20county\%2C\%20MI\&parsed=1\&cn=wayn e\%20county\&stc=mi.

\footnotetext{
70 See again CoreLogic Negative Equity Report, supra note 59.

71 Data from Zillow.com, http://www.zillow.com/visuals/negative-equity/\#4/39.98/-106.92. Some of what
} follows draws upon Hockett \& Vlahoplus, "A Federalist Blessing in Disguise," 9 Harvard J. Law \& Pol'y 1 (2013). 


\begin{tabular}{|r|r|r|r|r|}
\hline 33142 & Miami & FL & $62 \%$ & $-66 \%$ \\
\hline 30274 & Riverdale & GA & $85 \%$ & $-71 \%$ \\
\hline 30296 & Riverdale & GA & $84 \%$ & $-66 \%$ \\
\hline 30297 & Forest Park & GA & $81 \%$ & $-72 \%$ \\
\hline 89030 & North Las Vegas & NV & $77 \%$ & $-76 \%$ \\
\hline 89101 & Las Vegas & NV & $75 \%$ & $-76 \%$ \\
\hline 89106 & Las Vegas & NV & $72 \%$ & $-71 \%$ \\
\hline 89115 & Las Vegas & NV & $77 \%$ & $-72 \%$ \\
\hline
\end{tabular}

\section{B. Non-Mortgage and Aggregate Private Debt Overhang}

Moving beyond housing, other asset prices plummeted too with the 2008 crash, of course, just as they did in the late 1920s. Stock market prices dropped over $50 \%$ in both instances, for example. The two periods are difficult to compare in respect of stock prices after their crashes, however, for a straightforward reason: The Fed notoriously neglected to ease monetary policy in the wake of the 1929 crash, while it has been anything but timid in the wake of 2008. This means that debt overhang aggregates are harder to track in connection with stocks than they are in connection with housing.

A better way to round out the picture begun with mortgage debt overhang, then, is first to examine debt aggregates after the 2008 crash, and where possible to compare them to counterpart aggregates after the 1929 crash, then to examine new debt trends. Figure 17 is instructive in the first connection. It shows that, notwithstanding the great buildup in private debt levels leading up to the 2008 crash, very little private de-levering has occurred post-crash, while in fact we are already relevering. Indeed, we de-levered no more than $3 \%$ before beginning to re-lever. That stands in stark contrast to the over 50\% figure found after 1929, as shown further down in Figure 18.

Figure 17

\section{U.S. GDP, Private Debt, and Public Debt Trends 1998-2011 \\ (in billions)}

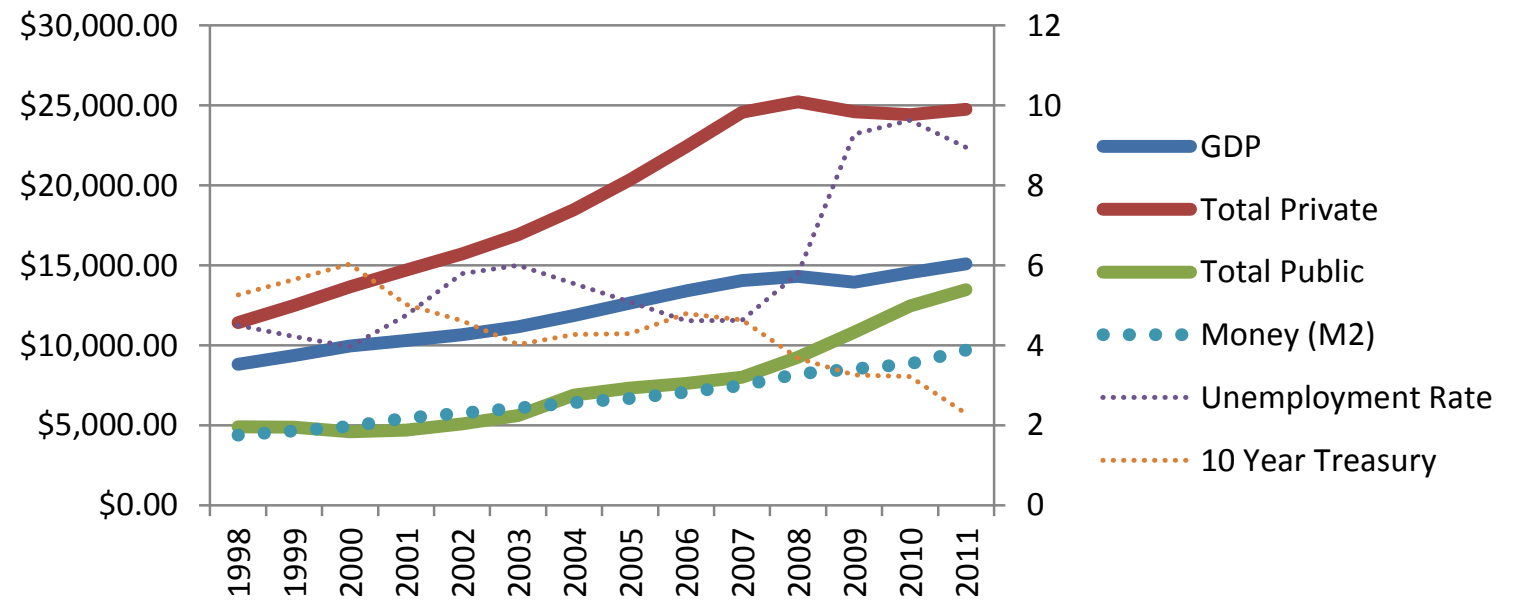




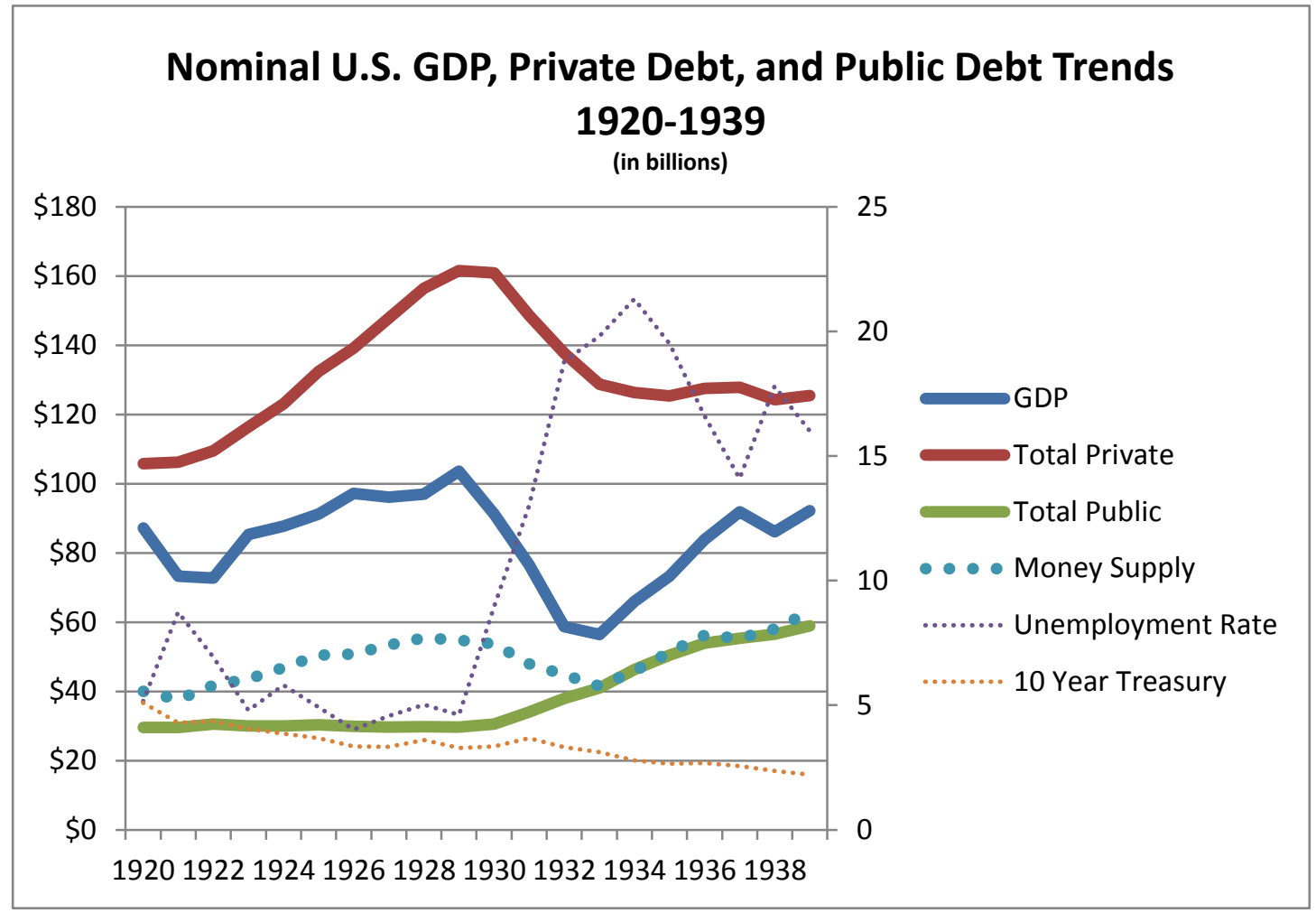

The difference in private de-levering patterns between post-1929 and post-2008 accounts for some additional differences between the two periods. ${ }^{72}$ Most salient among these is the lesser contraction of GDP after 2008, which has long since been recovered and modestly built upon, on the one hand, and the dramatic contraction of GDP after 1929 on the other. [Add numbers.] The only reason that the macroeconomy is not shrunken as it was in the 1930s, in other words - and employment rates with it - is that we are still floating on debt - nearly the same levels of private debt as before, but now on more public debt too, which debt-stifled private spending contraction necessitates.

Several other facts gleanable from Figures 17 and 18 bear noting while we are at it. One is that public debt levels did not grow significantly at all in the lead-up to 1929, the claims of public-debtblamers notwithstanding. Public debt levels did grow, notoriously, in the lead-up to 2008, but nowhere near as significantly as private debt levels. The other thing to note is that public spending associated with the New Deal was nowhere near as large as was private de-levering over the same period, which again stands in contrast to the post-2008 period as noted above.

A final point worth noting where aggregate debt levels are concerned has to do with a comparison that often is drawn between the present and the immediate post Second World War Era: It

72 Bank failures appear to have accounted for about a quarter of the total pay-down. [Source.] The larger point, however, is that private de-levering occurred to the tune of over $50 \%$. This Subpart draws in part upon Clemons \& Vague, supra note 1; and Hockett \& Dillon, supra note 21. 
is often pointed out, to those who have fretted over public debt levels since 2008, that the relevant figure is debt-to-GDP, and that the latter ratio was greater circa 1945 than it is now. That is quite correct, but only if we consider public debt in isolation. Add private debt to the picture and calculate total debt to GDP, and the figure is much higher than in 1945 or any other period, for that matter.

This can be seen in Figures 19 and 20 (the latter of which replicates Figure 11 shown earlier to spare page turning). Moreover, as Figures 21 and 22 indicate, private debt is typically by far the largest of salient aggregates in the macroeconomy, such that changes in this aggregate correlate more closely with changes in GDP than does any other indicator. This suggests two things. First, and again, that while it makes sense to fret over debt, it is private, not public debt that should worry us. And second, that if we really want to restore growth and employment significantly, we should focus on private debt write-downs, not pay-downs or public debt down-sizing.

Figure 19

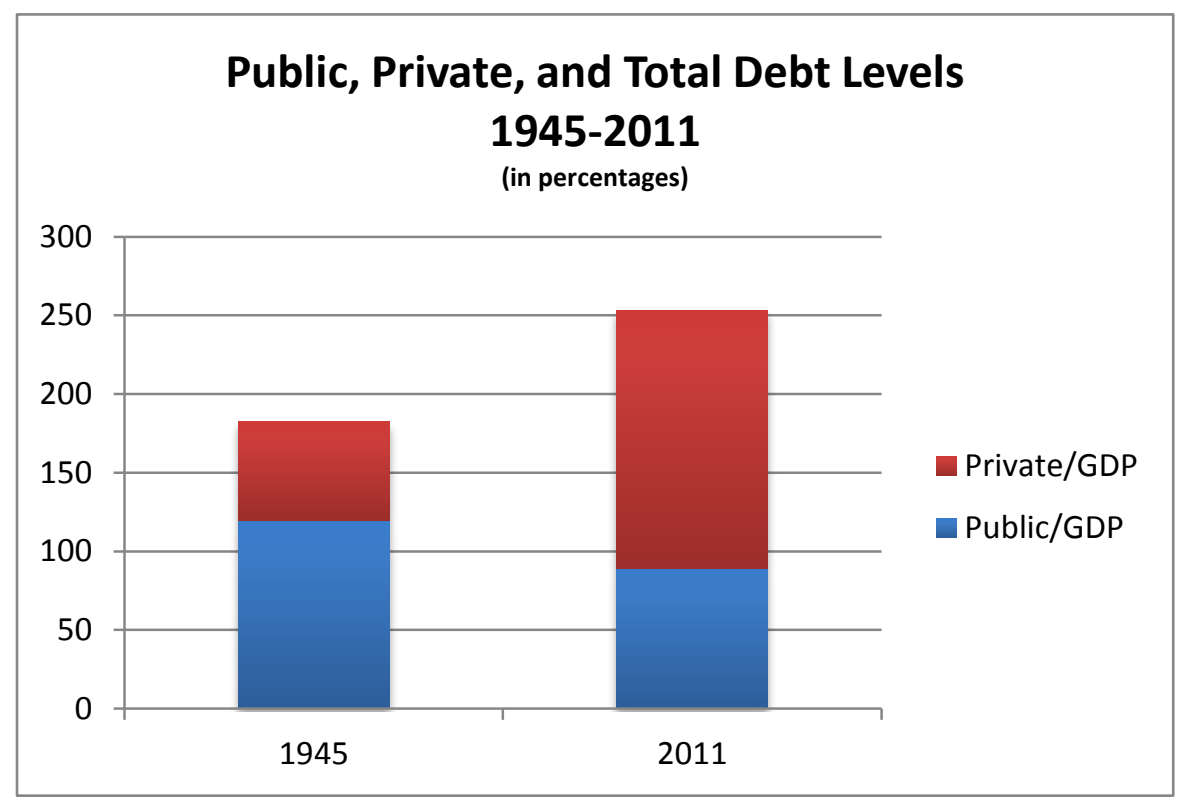

Figure 20

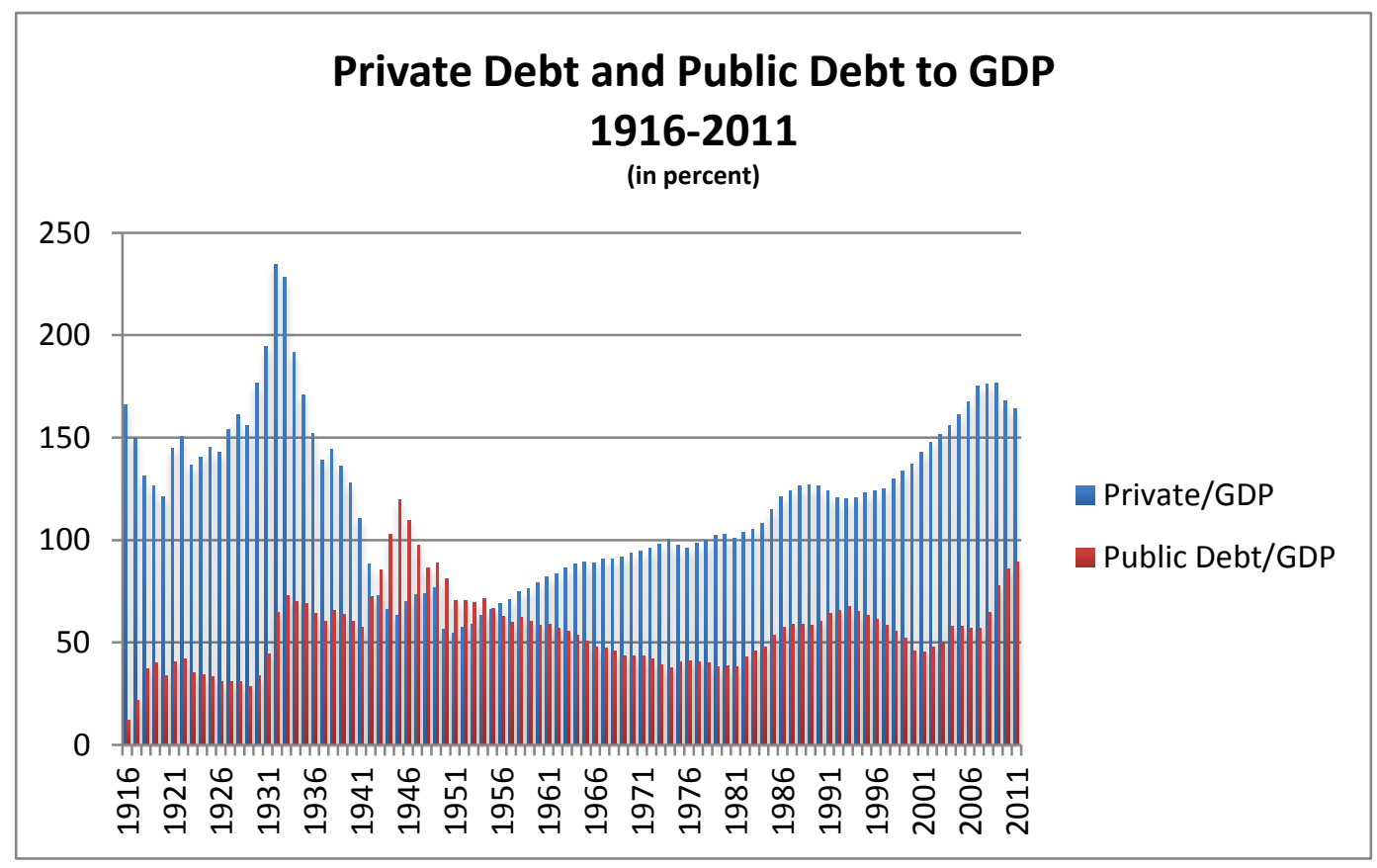


Figure 21

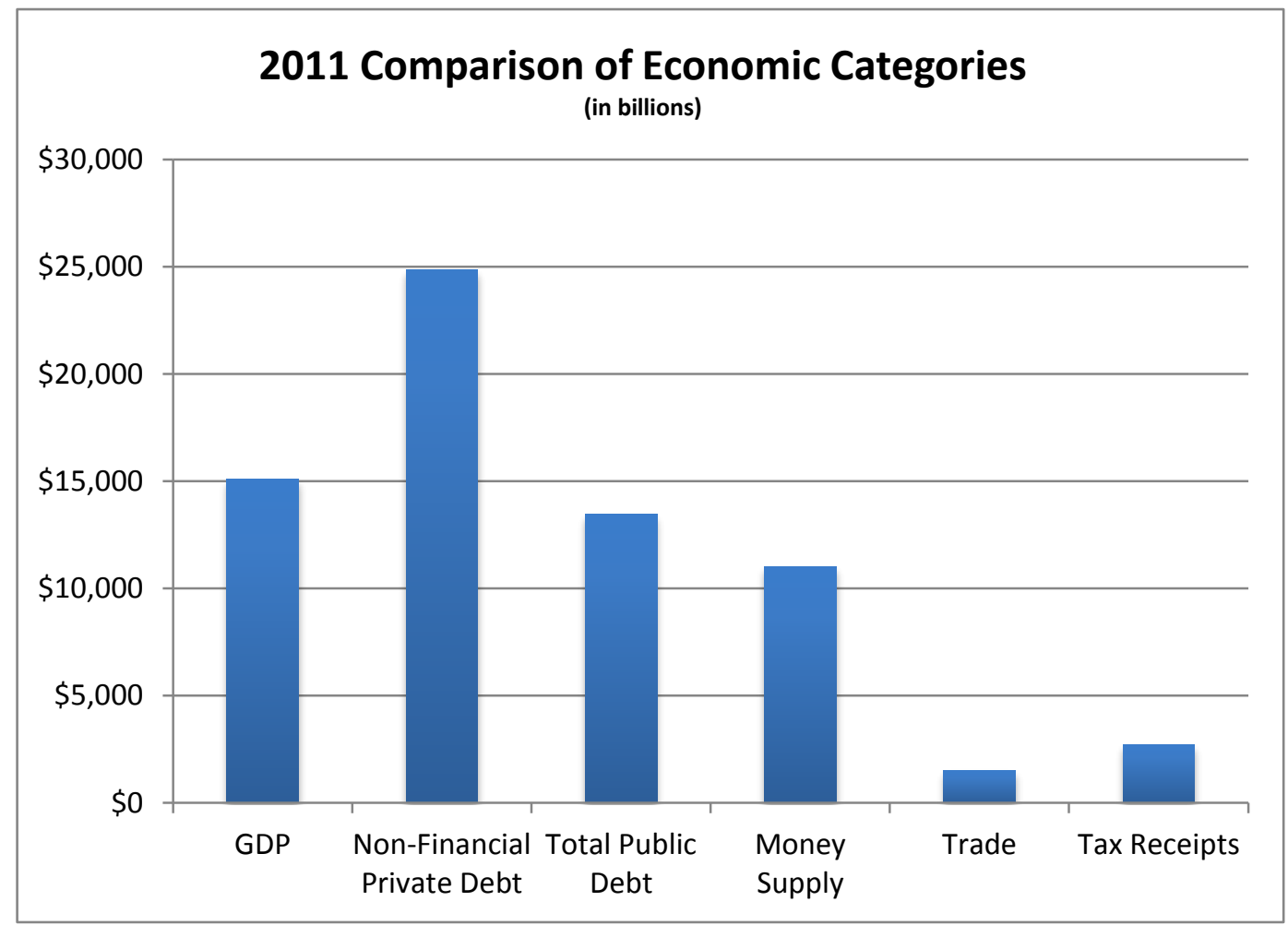

Figure 22

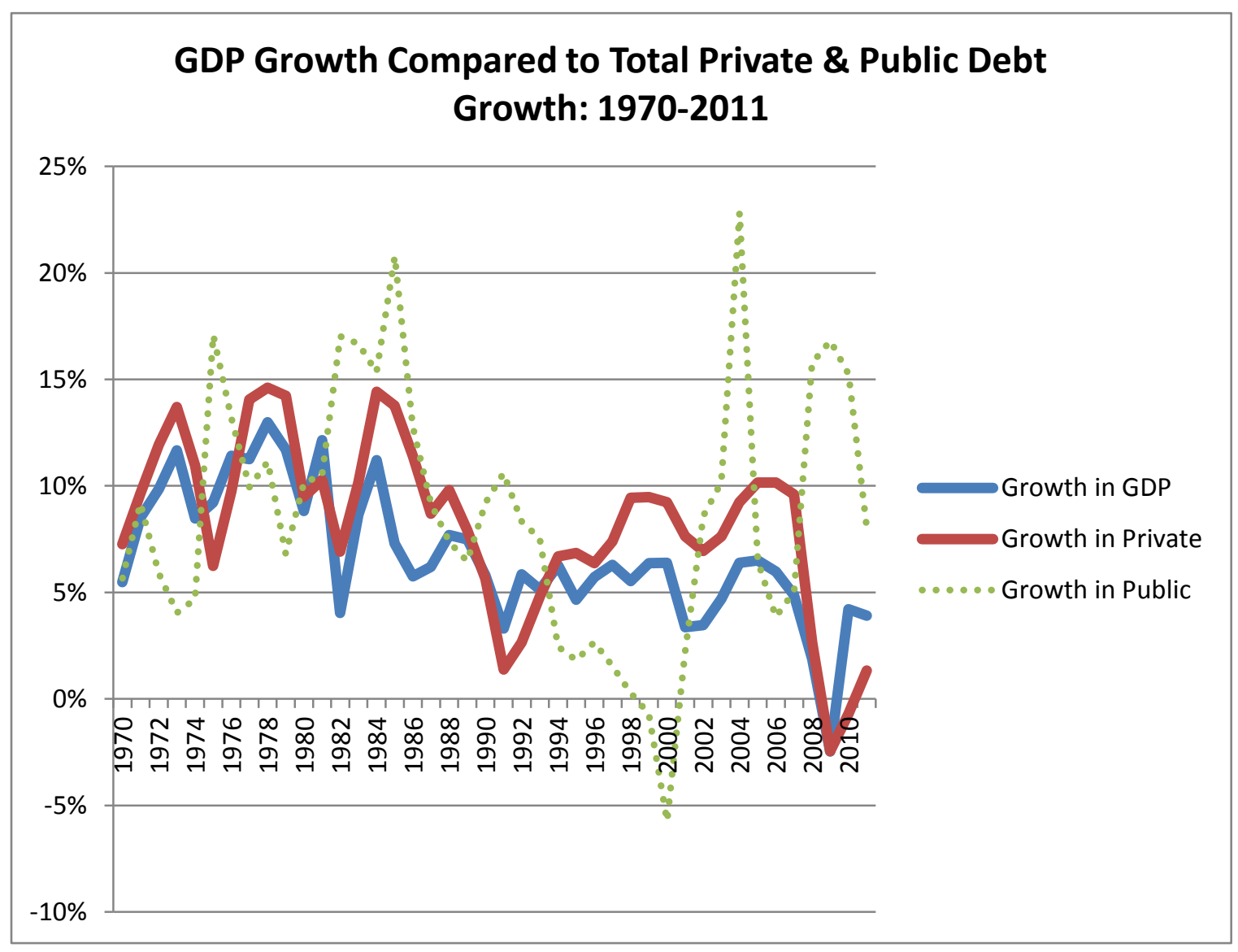


A final point that bears noting in connection with post-2008 private debt loads has to do with one category of debt that has grown markedly since the crash and appears poised to act as a significant drag upon consumer spending in years to come. That is the category of student debt, which in 2010 came for the first time to surpass credit card debt as the most significant category after mortgage debt.

According to recently released New York Fed data, total consumer indebtedness at the end of the year was $\$ 11.34$ trillion, up approximately 0.3\% from the third quarter. (See Quarterly Report on Household Debt and Credit, FRBNY, Research and Statistics Group, February 2013.) Non-housing debt in particular rose for a third consecutive quarter to $\$ 2.75$ trillion, up $1.3 \%$. Of this, in turn, nearly $\$ 1$ trillion is represented by student debt, which has risen at a steadily accelerating quarterly rate in recent years and rose over 70\% from 2004 through 2012 alone - the only category of private debt actually to rise during the Great Recession. Ninety day plus delinquency rates on these loans also have risen in recent years, and now stand at $11.7 \%$.

Some analysts see in these figures a looming crisis in its own right. Certainly the debt load afflicts a demographic that in past decades could be relied upon to add significantly to domestic housing and broader consumer demand. What is more, the growth in this debt does not seem to reflect mere profligacy on the part of the borrowers any more than did mortgage debt during the bubble. For one thing, tuitions have grown at a pace significantly outpacing inflation in recent years, as strapped states have diverted once reliable funding from state colleges and universities. For another thing, during the Great Recession, many have found further schooling necessary both to enhance marketability in a tightened job market and to use time while unemployed productively. And finally, the hit taken by wages and incomes during the Great Recession have simply made post-graduation debt loads harder to carry.

For these reasons we propose modest student debt relief along with mortgage debt relief when we turn to proposals in Part IV below.

\section{Consequent Low Growth and Employment}

The final elements of our present state to which we should attend are of course the economy's growth and employment rates themselves - the factors that render our debt deflation intolerable. Not surprisingly, given our model, growth and employment have been anemic at best since the 2008 crash. Such "recovery" as there has been has been slow, wavering, and as often remarked, (virtually) "jobless." Figures 23-25 provide a snapshot. The first shows the growth trend-line since 2008 . The second two show employment ratio terms to avoid "discouragement distortion." 
Figure 23

\section{Real GDP Growth since 2008}

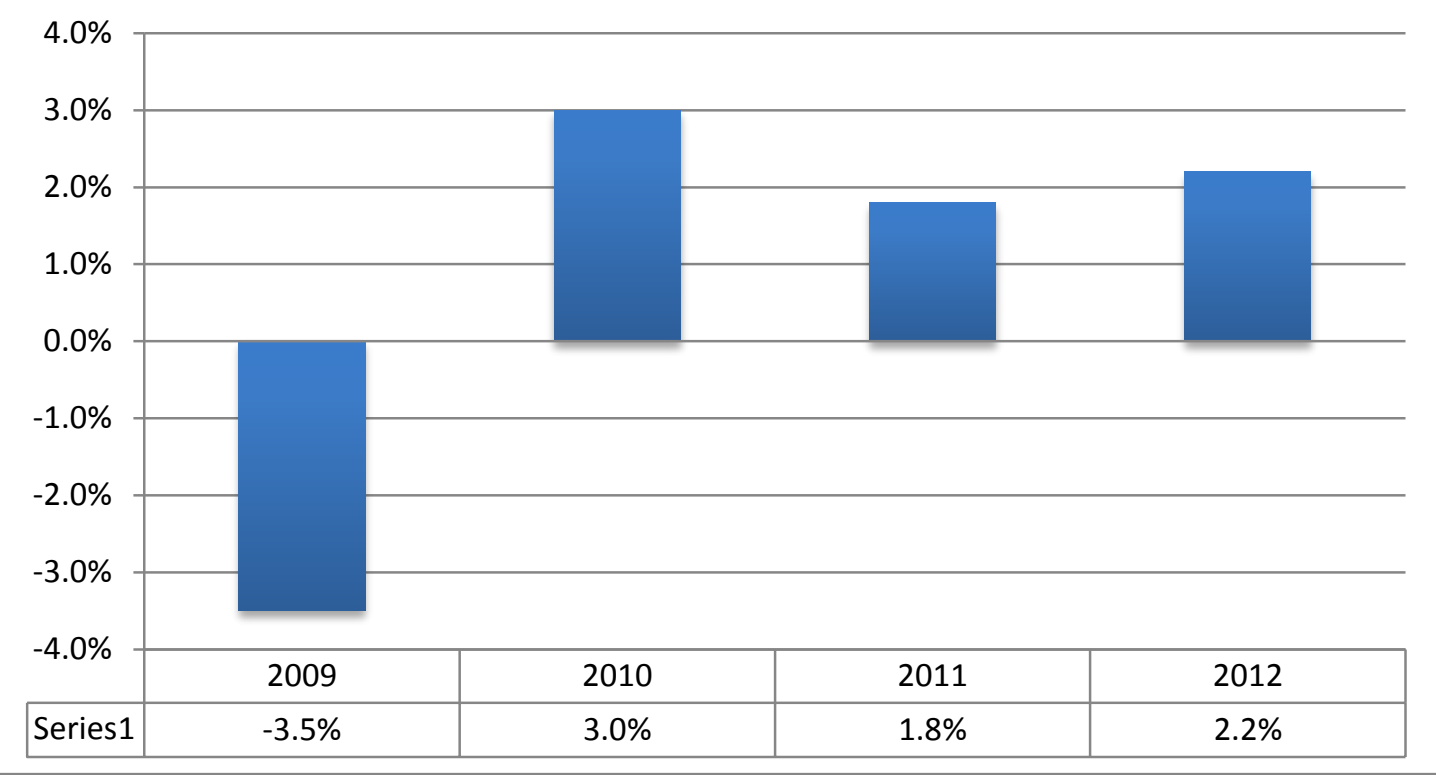

Figure $\mathbf{2 4}$

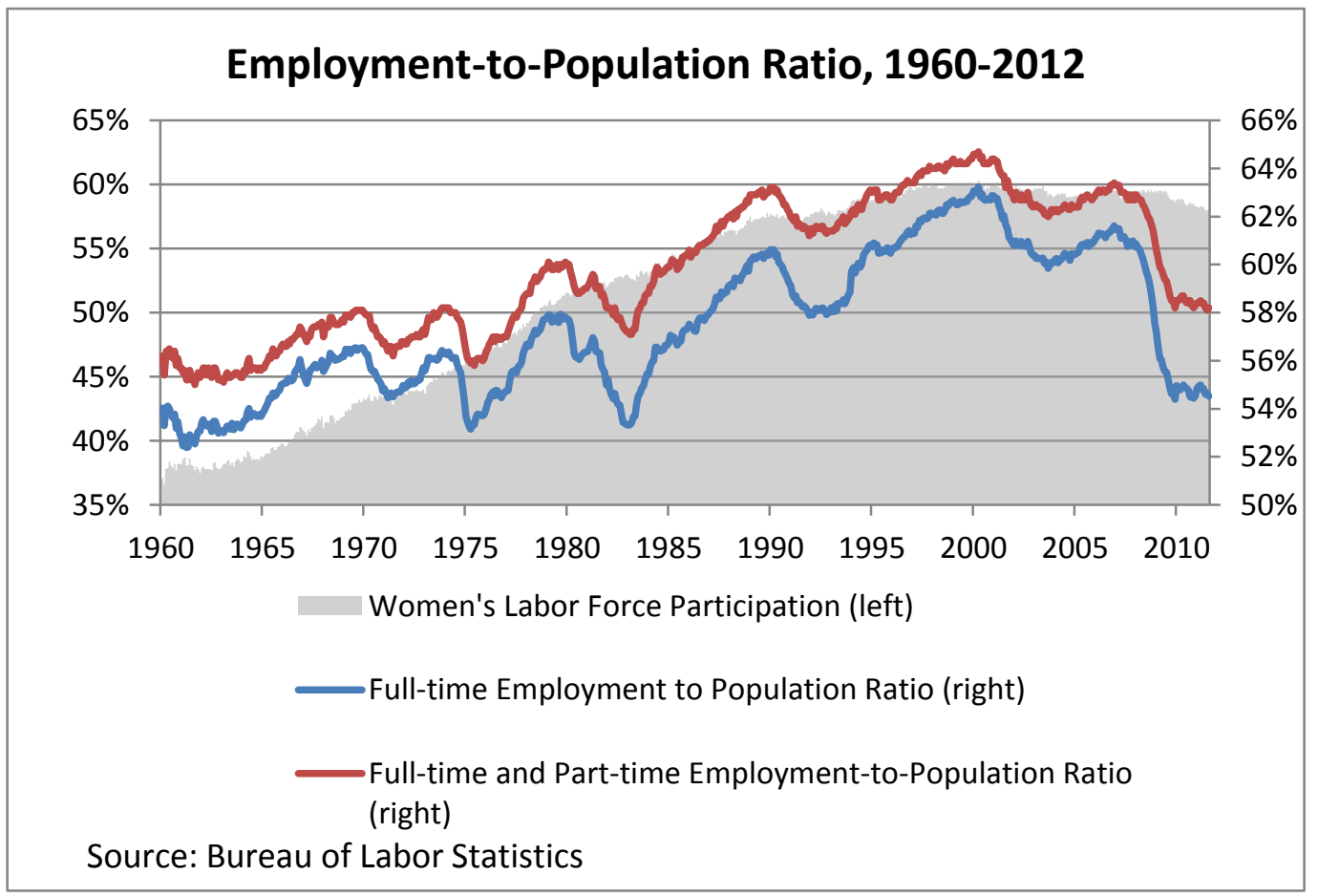




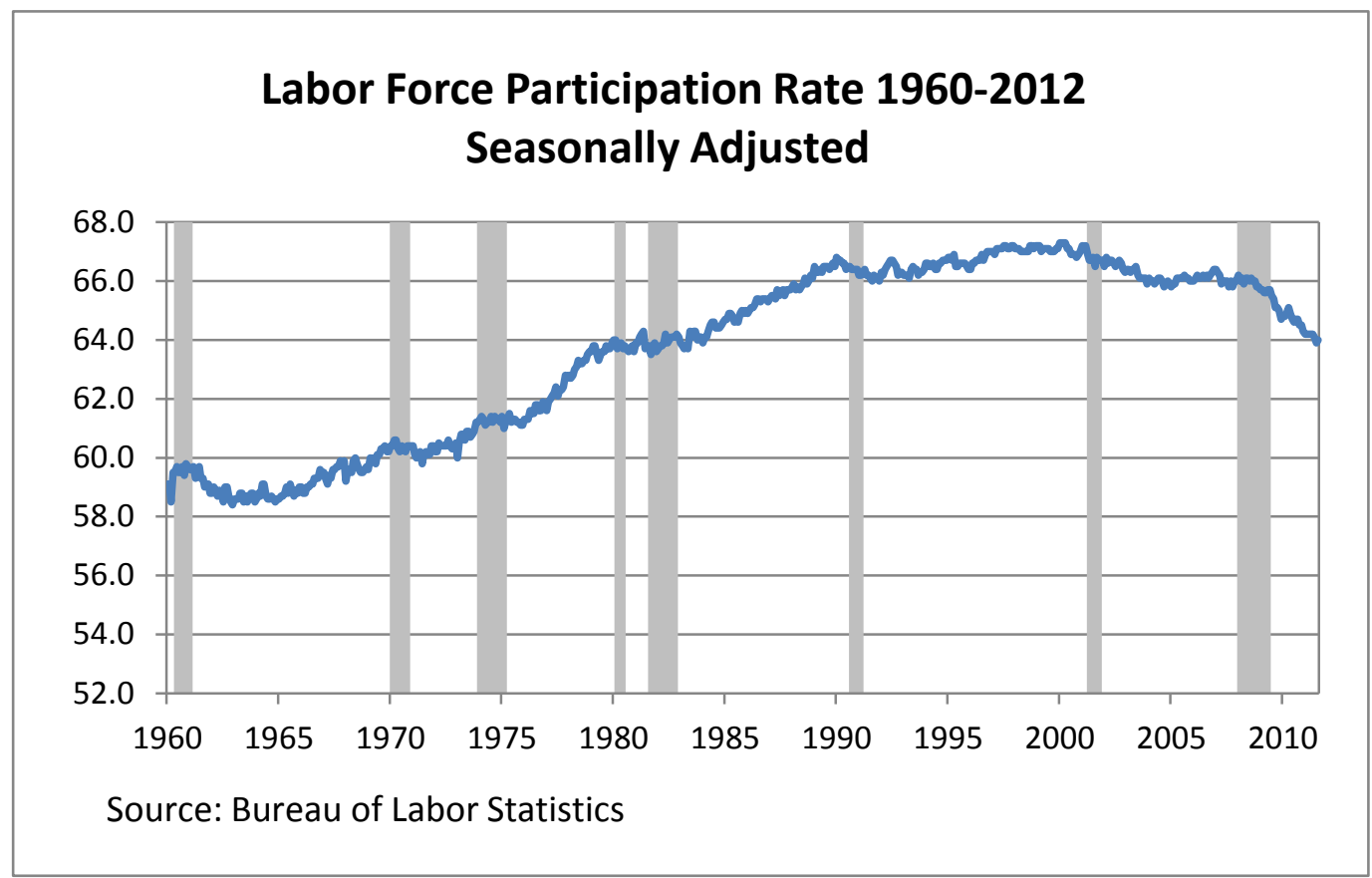

If our explanation of the foregoing data is correct, then the data themselves suggest that one of the most urgent tasks before us right now as a polity is to eliminate private debt overhang and thereby restore real growth and employment.

\section{Leaving the Water and Staying Dry: How to Do It}

We now turn to how best to address the private debt overhang problem and, thereby, the continuing macroeconomic dysfunction that this problem underwrites. We offer the proposals that follow knowing that each will tend to occasion at least some controversy, such that all will ultimately require significant additional detail and fuller discussion. We also note here that one of us is engaged in significant efforts "on the ground" at the time of this writing to implement each of the solutions here recommended. In that sense, this paper is partly a preliminary justificatory explanation of a number of macroeconomic repair initiatives already being pursued.

\section{A. Writing-Down Mortgage Debt}

We begin with means of writing-down private debt. Our principal, but not sole, focus will be on residential mortgage debt. Our reasons are several. First, residential mortgage debt overhang is by far the greater part of the national private debt overhang, proportionally speaking, as Figure 7 above might lead one to anticipate and as Figure 26 now indicates. 


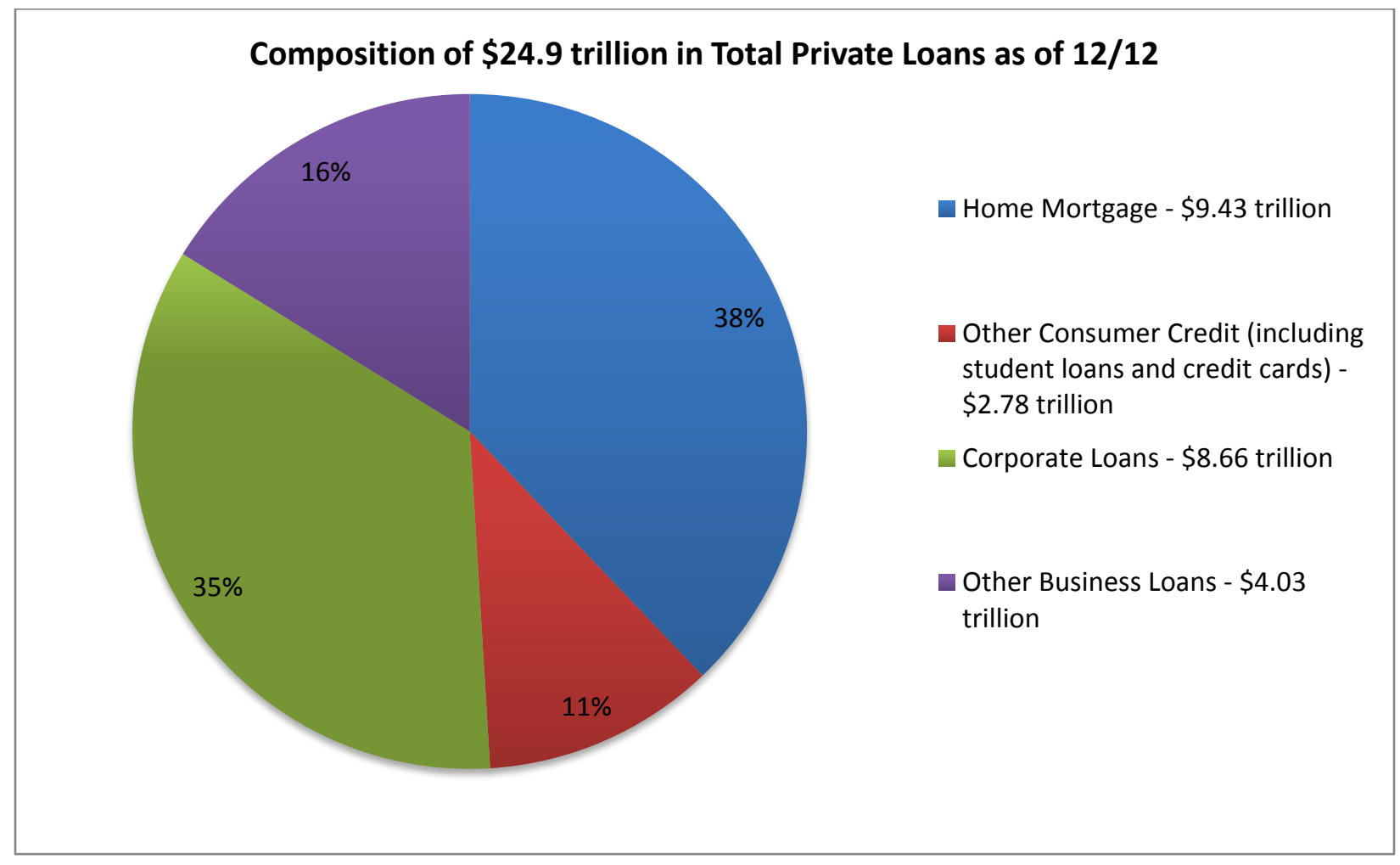

Second, mortgage debt overhang operates as by far the greatest drag upon post-bust consumer expenditure, owing to residential real estate's status as principal middle class asset. And finally third, mortgage debt write-downs are those least apt to implicate fairness or moral hazard concerns, for reasons that we shall explain. We'll also, however, offer some recommendations concerning student and general consumer debt after first covering mortgage debt.

Turning now to means of writing down mortgage debt, note first that the aggregate can be partitioned into three classes, according to who holds the debt. First there is privately-held, whole-loan portfolio debt, held primarily by depository institutions. Then there is GSE-held whole loan and securitized debt. Finally, there is privately held, private label securitized (PLS) debt, held primarily in the (secondary) form of mortgage-backed securities (MBS) owned by pensions and other investment funds. This category accounts for some $60 \%$ of the negative equity aggregate. We first examine means of writing down principal for each of these three classes, then discuss the important matter of regulatory forbearance and tax incentives as means of further facilitating principal reduction.

\section{Bank Portfolio Loans: Keep Up the Good Work - and Extend It}

The next thing to note is that, because underwater loans are subject to pronounced default risk as noted and partly quantified earlier, and because foreclosure and REO-holding are expensive as also noted earlier, the expected values (EVs) of many underwater loans can actually be raised by writing 
down principal. ${ }^{73}$ This in turn means that it is ultimately in the financial interest of creditors themselves to write mortgage debt down to sustainable levels. ${ }^{74}$ And this fact is confirmed by significant and still growing rates of voluntary write-down on the part of portfolio loan holders - principally commercial banks. $^{75}$

These rates are still lower than need be the case, however, and we suspect that this might stem in part from regulatory imperatives. We shall accordingly recommend a particular form of regulatory forbearance and tax incentive package, below, that can induce more in the way of principal writedowns. In addition, the bridge loan program discussed below in Subsection 4 should encourage more in the way of portfolio write-downs as well.

Whatever the future story of further portfolio loan write-downs, we note now that the GSEs and private holders of PLS debt have not been managing even that modest but growing degree of writedown activity that we find among portfolio lenders. That invites the question "why?"

\section{GSE Loans: Focus on the GSE Balance Sheets, not the Broader Public Fisc}

In the case of the GSEs, the problem appears to be almost entirely attributable to the way in which public benefits and costs brought by write-downs are calculated by their regulator, the Federal Housing Finance Agency (FHFA). ${ }^{76}$ FHFA thus far declines to permit the GSEs either (a) directly to writedown principal on their portfolio loans, or (b) to exercise their market power, in the case of their MBSunderlying loans, to induce the banking and other institutions that service those loans to do likewise. ${ }^{77}$ This is so notwithstanding the data that the GSEs themselves report to the SEC, noted above, in respect of the default rates among their underwater loans from which their own revenues derive.

There appear to be two reasons for this, both of them revealed in publicly released FHFA memoranda to which we have just cited, concerning the likely benefits net of costs that would be

\footnotetext{
73

See Hockett, "It Takes a Village," supra note 2; and Hockett, "Paying Paul," supra note 2. Also Hockett, "A Solution for Underwater Mortgages: Eminent Domain," Reuters, June 19, 2012, at http://blogs.reuters.com/greatdebate/2012/06/19/a-solution-for-underwater-mortgages-eminent-domain/; and Hockett, "The Eminent Domain Solution," Boston Review, Nov./Dec. 2012, at http://www.bostonreview.net/BR37.6/ndf robert hockett debt forgiveness.php. 74 Idem.

75 See Hockett, "It Takes a Village," supra note 2; and Hockett, "Paying Paul," supra note 2; and Goodman sources cited therein.

76 See Hockett, "It Takes a Village," supra note 2; and Hockett, "Paying Paul," supra note 2.

77 See, e.g., sources cited idem.; and additional sources cited therein. See, in particular, Edward DeMarco, "Addressing the Weak Housing Market: Is Principal Reduction the Answer?," Remarks Delivered at the Brookings Institution, April 10, 2012, available at http://www.brookings.edu/events/2012/0410 housing demarco.aspx; and "Letter from Edward DeMarco, Acting Director of the Federal Housing Finance Agency to Congressman Elijah Cummings, Ranking Member, Committee on Oversight and Government Reform," January 20, 2012, available at http://www.google.com/url?sa=t\&rct=j\&q=fhfa\%20letter\%20to\%20cummings\&source=web\&cd=2\&ved=0CDIQFjA B\&url=http\%3A\%2F\%2Fwww.fhfa.gov\%2Fwebfiles\%2F23056\%2FPrincipalForgivenessltr12312.pdf\&ei=xap T8TCGJ Ph0wH7 rT4Bw\&usg=AFQjCNF958kOhIVkOCBFW3rKmicBnBvd1g.
} 
occasioned by write-downs within the GSEs' portfolios. One is that FHFA's analyses assume that writedowns would be effected via the federal Home Affordable Mortgage Program (HAMP), which pays servicers to do what is already in the interest of those to whom their fiduciary duties ultimately run the creditors whose portfolio EVs would be raised by writing down deeply underwater mortgage loans. Since HAMP fees are public costs, FHFA deducts them from the public benefits that would accrue from write-downs among loans in the GSE portfolios. The other, related reason is that FHFA appears to view the losses apt to be booked by financial institutions holding second liens on underlying properties as public costs too, which it likewise accordingly deducts from the benefits that would be wrought by write-downs.

Against this backdrop, there are three solutions that immediately present themselves. The first is for the GSEs simply to refrain from resorting to HAMP in conducting and inducing write-downs. Because they can do this without servicers, there is no need to pay servicers out of the public fisc to do what is in the interest of their own principals. The second solution is regulatory forbearance and tax incentivization of the sort that we elaborate further below, which should moot FHFA's apparent concern for the second-lien-holding banks that it neither regulates nor holds in conservatorship. Finally, the third solution is to require FHFA not to weigh costs and benefits to the "United States" in determining what to require of the GSEs that it regulates and currently holds in conservatorship, but to weigh costs and benefits to those GSEs themselves, which are its proper focus. Costs and benefits inuring to the United States are the proper concern of Congressional and White House budget offices, not of "silo'ed" special purpose regulators.

\section{PLS Loans: Bankruptcy Workout \& Eminent Domain}

Turning from GSE-held to private label MBS, here the problem is not regulatory failure, but market failure. ${ }^{78}$ While the failure in question is complex in character, the two principal components both stem from the specific arrangements pursuant to which the relevant mortgage loans were securitized during the bubble years: First, the fragmented beneficial ownership interests in securitized mortgage loans induce classic creditor collective action problems where debt forgiveness is concerned; widely dispersed creditors cannot even find one another, let alone agree either unanimously or in supermajoritarian fashion to mutually beneficial debt write-downs. And second, the pooling and servicing agreements (PSAs) pursuant to which the relevant loans were securitized, drafted as they were during the bubble years when few seem to have anticipated market-wide crash and all rushed to push or to purchase newfangled product, for the most part do not permit trustees, servicers, or other collective agents to cut through the aforementioned creditor collective action problems. ${ }^{79}$

Because solving the second of these mentioned problems will likewise solve the first of them, solution of the PLS mortgage debt problem must target the mentioned PSAs. These are, of course,

\footnotetext{
78 See Hockett, "It Takes a Village," supra note 2; and Hockett, "Paying Paul," supra note 2. .

Idem. Also Hockett, "Six Years On," supra note 56; and Robert Shiller, "Reviving Real Estate Requires Collective Action," New York Times, June 23, 2012 (Hockett mentor endorsing the eminent domain plan), at http://www.nytimes.com/2012/06/24/business/economy/real-estates-collective-action-problem.html? $r=0$.
} 
contracts. This means in turn that no solution that does not replace these contracts, which now function effectively as financial suicide pacts among bondholders, with more functional arrangements will succeed. There are only two authorities by which this can be done. One is the bankruptcy-oversight authority vested in our bankruptcy courts by the federal Constitution and the Bankruptcy Code. The other is the eminent domain authority that our federal and state constitutions respectively confer upon our federal, state, and local governments.

\section{a. Bankruptcy Workouts: Legislation or Lease Swaps}

As it happens, the Bankruptcy Code is not at present helpful for our purposes, owing in part to what was at the time a surprising 1993 Supreme Court decision, Nobelman v. American Savings Bank, that interpreted the Chapter 13 "primary residence" exclusion from bankruptcy protection in an unexpected way. ${ }^{80}$ Chapter 13 excludes primary residences from bankruptcy protection, but it does not, by its language or legislative history, exclude overhang when prices fall below nominal debt obligations. ${ }^{81}$ Yet that is how Nobelman read it, and the bankruptcy courts have accordingly chafed ever since. Were Nobelman to be expressly overruled, then, either congressionally or judicially, we would have one route to mortgage debt write-downs in the form of so-called "strip down."

A more plenary route to solving the problem would be to amend the Bankruptcy Code itself to remove the primary residence exclusion altogether. Some members of Congress have tried twice now and failed to do this post-2008, via the so-called "cram-down" legislation introduced in 2009 and $2010 .^{82}$ Regrettably, however, neither attempt has got past committee in the House of Representatives, and the White House has thus far not pushed the legislation. That could change, and the change would be more than welcome.

In the absence of legislative or judicial action to overturn Nobleman and legislative action to amend Chapter 13 in more plenary fashion, there is but one remaining bankruptcy-levering route to go. That is the use of what one of us has proposed and advocated under the name of "lease swaps" over the past several years. ${ }^{83}$ The idea here is for underwater home-owners in the same neighborhoods literally to swap residences under leasing arrangements, then file for bankruptcy under Chapter 13 to writedown their mortgage debt overhangs. ${ }^{84}$ Homeowners wishing to do this could make use of the extensive "home-swapping" infrastructure that has developed on the web during the crisis years. ${ }^{85}$ Or they might visit a website that both instructs them on how to do this and brings them directly together, currently under construction by the aforementioned co-author of this paper.

\footnotetext{
$80 \quad 508$ U.S. 324 (1993). See also Hockett, “Six Years On," supra note 56.

$81 \quad 11$ U.S.C. $\$ 1322(b)(2)$. See generally Hockett, "Six Years On," supra note 56.

82 See Hockett, "Six Years On," supra note 56.

83 See, e.g., Hockett, “Home Lease Swapping as Mortgage Market Cure," Benzinga, October 14, 2011, at http://www.dorfonlaw.org/2011/10/post-by-bob-hockett-lease-swaps-as.html; and Hockett, "Lease Swaps as Underwater Mortgage Cure," Dorf on Law, October 16, 2011, at http://www.dorfonlaw.org/2011/10/post-by-bobhockett-lease-swaps-as.html.

$\begin{array}{ll}84 & \text { Idem. } \\ 85 & \text { Idem. }\end{array}$
}


This plan might be thought "too cute" or "too clever by half" in its reliance on a very "plain meaning" approach to the "primary residence" exclusion. In fact, however, it appears to be widely agreed that bankruptcy judges chafe under the misguided Nobelman decision, and have accordingly read the statutory language very literally ever since so as, for example, to rule the exclusion inapplicable to homes whose owners have moved out of them. ${ }^{86}$ In this light, the bankruptcy bench and bar should be expected to welcome another opportunity to get out from under the "primary residence" exclusion. The lease swap method affords them this opportunity. Figure 27 diagrams how the plan works.

Figure 27

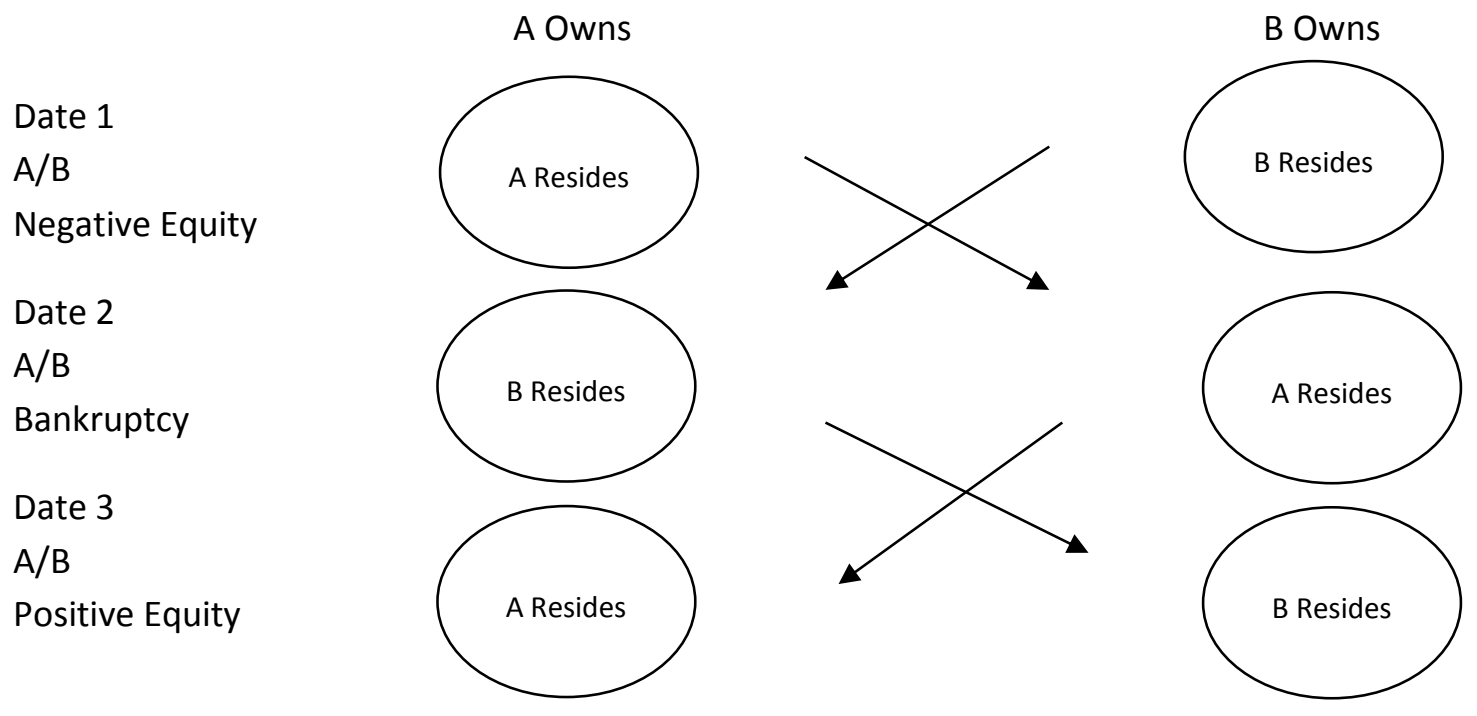

Note: Arrows represent residence swaps pursuant to lease contracts. Ownership in fee simple vests with original owners throughout .

The diagram, read from top to bottom, shows owners A and B residing in their own homes at Date 1, each with negative equity. At Date $2, A$ and $B$ lease their homes to one another, changing "primary residences" within the meaning of Chapter 13, and file for bankruptcy in order to obtain "strip down" of mortgage debt overhang. At Date 3 , if they wish, A and B resume residing in the homes that they own, no longer underwater.

\section{b. Eminent Domain: Public Facilitation and Private Financing}

Turning from bankruptcy and lease swaps to eminent domain, the idea here is for governments to sidestep the PSA contract rigidities that lie at the heart of our problem by "taking" underwater loans at fair value, then replacing them with better written loans that leave homeowners with some positive equity. ${ }^{87}$ Because this is ultimately a way of recouping value for ultimate creditors themselves in

86 See, e.g., Lynn M. LoPucki, "House Swaps: A Strategic Bankruptcy Solution to the Foreclosure Crisis," forthcoming in Michigan Law Review (2013) (taking up and elaborating on Hockett Lease Swap proposal).

87 See Hockett, "It Takes a Village," supra note 2; and Hockett, "Paying Paul," supra note 2. 
addition to homeowners, the ideal way to finance this operation would be with moneys supplied by the affected MBS holders themselves. ${ }^{88}$ In effect, the latter would be "paying themselves" the fair values of the loans, then receiving the new, higher-value loans by way of payback. This two-step process would be financially identical to a single-step write-down, with the second step amounting to no more than a straightforward consequence of a government actor's having to be brought into the structure in order to get past the PSA. ${ }^{89}$ Figure 28 diagrams the basic structure.

Figure 28

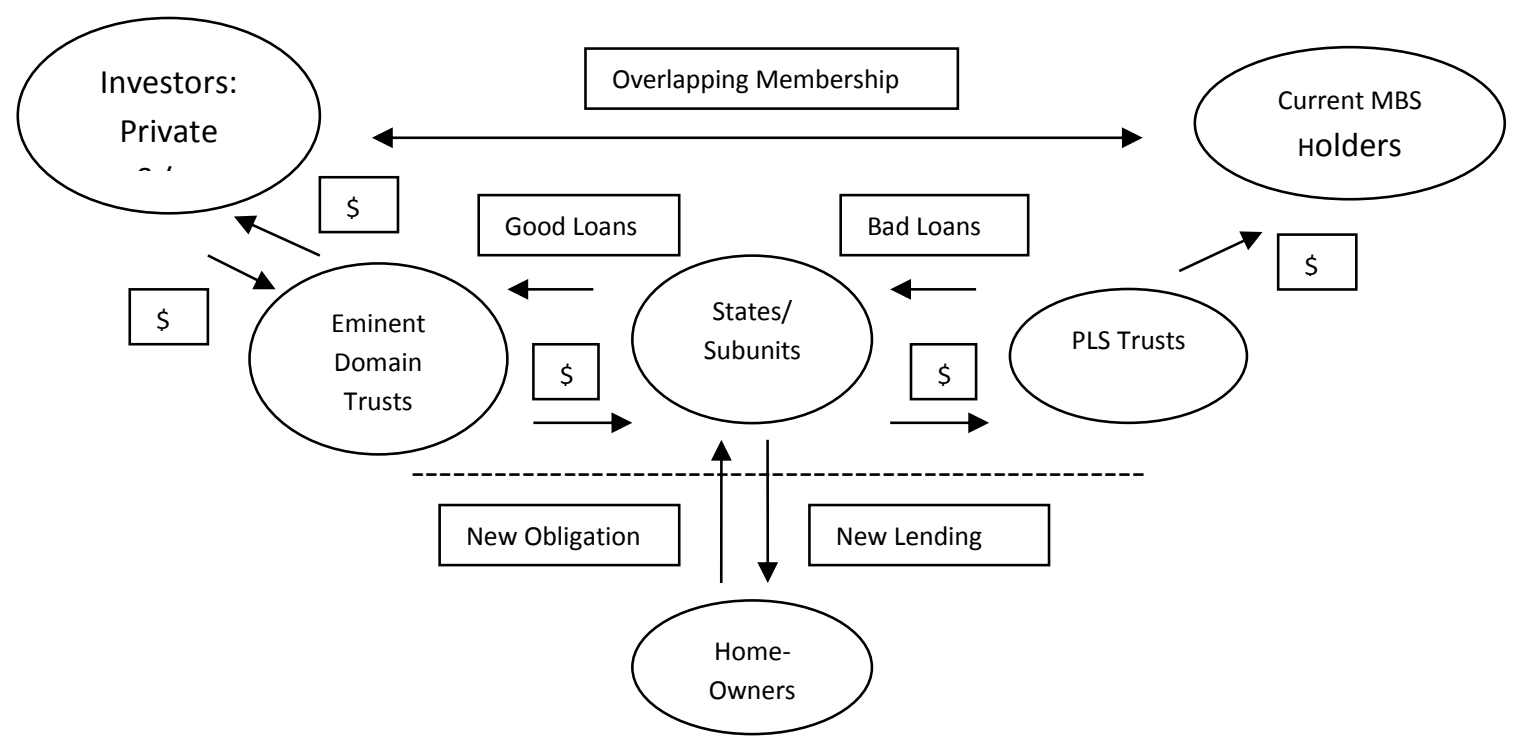

Note: The double-headed arrow represents class overlap rather than a flow. The two vertical arrows crossing the dotted line represent a detour between the "bad loan" and "good loan" arrows.

The diagram, read counterclockwise, shows investors, including current bondholders with funds perhaps supplemented by financing from federal agencies, conveying funds to eminent domain trusts operated by government instrumentalities - probably states or their subunits. These eminent domain trusts then purchase deeply underwater ("bad") loans from private-label securitization trusts. The states or their sub-units, in most cases perhaps advised or otherwise assisted by financial professionals, then work with homeowners to write new mortgages, replacing the negative equity loans with modestly positive equity loans - probably thirty-year fixed-rate mortgages in all cases. ${ }^{90}$ Finally, the new ("good") loans are conveyed to the first-mentioned trusts, which convey resultant funds to the first-mentioned investors.

\footnotetext{
$88 \quad$ Idem. Also Hockett, Reuters op-ed and Boston Review essay cited supra, note 73.

89 Idem.

$90 \quad$ Freeing the loans from their PLS trusts, it bears noting, renders them eligible for the Federal Housing Administration Short Refinance, Hardest Hit Funds, and HAMP Principal Reduction Alternative programs.
} 
The payouts will in most cases take the form that payouts on the earlier, unmodified loans took - bond yields to bondholders. And, as noted earlier, the new bondholders should include as many of the original bondholders as wish to participate, since the aim of the plan is to enable homeowners and bondholders to do what the pooling and servicing agreements now prevent them from doingmodifying underwater loans to recoup presently lost value.

What level of government should play the appointed role here? As mentioned earlier, one of the authors of the present paper has sketched multiple variants on the plan per which differing government instrumentalities play the role. ${ }^{91}$ Probably the best situated at present, owing both (a) to the locally concentrated nature of the problem as noted above, and (b) to the current paralysis in Washington also noted above, are state and local authorities. ${ }^{92}$ The mentioned co-author is working at present with multiple such authorities on plans of the just-described kind. He also is meeting with bondholders and federal officials on a regular basis, both to keep them apprised of developments and to engage their expertise or participation. Readers might be aware of some of this work in connection with media reports out of San Bernardino, California in the second half of 2012 and Brockton, Massachusetts more recently, but there is much more afoot here than can be currently reported.

There are multiple ways in which federal instrumentalities can play a supporting role, and earlier variations on the plan were first proposed by the present co-author to some of those instrumentalities themselves during the 2008 debates over TARP. Fed and Treasury can facilitate municipal, homeowner, and bondholder summits on loan selection and valuation criteria, for example. ${ }^{93}$ They also can use their good offices to ensure that rewritten loans per the plan retain access to the FHA short refi program, and even encourage the FHFA and the GSEs to purchase resultant loans so long as they are, as they will be, "conforming." Fed for its own part can do such purchasing too, per QE3. And finally, Treasury (principally through OCC) and FDIC can act in a number of ways to encourage banks in both their portfolio loan holding and their loan servicing capacities to cooperate with these efforts. ${ }^{94}$

\section{Piggy-Backing on Bridge Loan Assistance Programs}

Another way to get more in the way of mortgage loan principal reduction, at least from portfolio loan holders, is by levering, in a particular way, another initiative with which one of the present coauthors is associated. ${ }^{95}$ We refer to mortgage bridge loan programs offered by some states and,

\footnotetext{
91 In addition to sources cited supra, note 76, see, e.g., Hockett, "Bailouts, Buy-Ins, and Ballyhoo," supra note 2; Hockett, "Solution for Mortgage Crisis and Looming Global Financial Crisis is in Historical Record," Cornell Chronicle, November 5, 2008, at http://www.news.cornell.edu/stories/2008/11/hockett-history-key-solvingfinancial-crisis; and Hockett, "Treasury's Planned Bailout is FHA's Bailiwick," Dorf on Law, September 25, 2008, at http://www.dorfonlaw.org/2008/09/treasurys-planned-bailout-is-fhas.html.

92 See supra, Part III.A. For fuller elaboration, see Hockett, sources cited supra notes 2 and 73.

93 On this point, see in particular Hockett, "Paying Paul," supra note 2.

94 On all of these points, see idem.

95 See Hockett, "The Home Mortgage Bridge Loan Assistance Act of 2012," at
}

http://papers.ssrn.com/sol3/papers.cfm?abstract id=1987093; and Campbell \& Hockett, "White Paper in Support of the Home Mortgage Bridge Loan Assistance Act of 2012," New York City Bar Association White Paper, at 
perhaps in future, a federal instrumentality as well. ${ }^{96}$ Pennsylvania's Home Emergency Mortgage Assistance Program (HEMAP), commenced during the steel slump of the early 1980s, is the original inspiration here. New York appears to be poised to enact a counterpart statute drafted by one of the present co-authors, which builds on 30 years of Pennsylvania experience with HEMAP.

What plans of this sort do is make mortgage payments on behalf of beneficiaries who suffer temporary difficulty in keeping current on their obligations owing to temporary un- or underemployment of the kind associated with macroeconomic slump. ${ }^{97}$ Because the underlying loans are sound and the un- or underemployment periods typically less than 2-3 years in duration, these programs enjoy high success rates - typically greater than $80 \%$ repayment rates, with thousands of likely foreclosures prevented. ${ }^{98}$ For this reason, in turn, both banking and housing advocacy organizations tend to favor these programs, as of course do homeowners and legislatures.

The way in which such plans can encourage further principal reduction is simple: Only structurally sound loans meet program eligibility criteria, and structural soundness excludes high postbust LTVs. A bank faced with an underwater loan in imminent danger of default and consequent costly foreclosure proceedings, then, already faced with significant but not yet decisive incentive to write down debt, is apt to be nudged the rest of the way by the prospect of two to three years' guaranteed payment. Such payment's contingency upon a write-down will in such case suffice to bring on that welcome result.

\section{Regulatory Forbearance \& Tax Incentives}

A final, and very important way to get more in the way of mortgage loan principal write-downs is by regulatorily making it easier for some institutions to do them. ${ }^{99}$ This stems from the fact that, at least initially after some write-downs, some institutions will become de-capitalized to the point that post-Basel III capital requirements end up effectively prescribing the impossible - viz. that financial institutions raise equity during a time of intense uncertainty.

Regulators might accordingly consider enabling institutions to open Special Asset Resolution Suspense Accounts (SARSA), into which would be booked any and all losses arising solely from voluntary principal reductions by lenders. Amounts posted to the SARSA would, for regulatory and GAAP accounting purposes, be permitted to be amortized in equal amounts over a 10 to 20 year horizon,

http://papers.ssrn.com/sol3/papers.cfm?abstract id=1987159. See also Hockett \& Campbell, "Some Homeowners Need Just Temporary Aid," American Banker, May 24, 2012, at http://www.americanbanker.com/bankthink/Mortgage-bridge-loan-New-York-City-Bar-1049605-1.html; and Hockett \& Campbell, "A Bridge to Viable Mortgages," Albany Times Union, June 14, 2012, at http://www.timesunion.com/opinion/article/A-bridge-to-viable-mortgages-3635265.php.

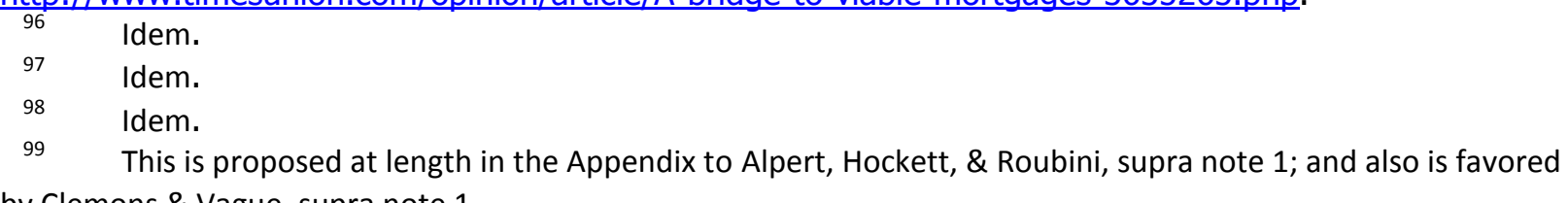
by Clemons \& Vague, supra note 1. 
rather than being fully booked as losses during the years incurred. In effect, this would constitute a straightforward counterpart to a strategy successfully employed by FSLIC in the late 1980s with a view to incenting healthy thrift institutions into purchasing failed such institutions. That was the use of "regulatory goodwill" capital, amortized per the "straightline method," in order to "buy time" for cooperating institutions aiming to bring themselves into compliance with the capital requirements of the day after assisting FSLIC in its "mop up" operations after the S\&L bust. To incent financial institutions to restructure with borrowers, we propose a tax credit be provided over this same 10 to 20 year period that would cover the institution's costs and provide the institution with incentive.

SARSA treatment also would not be available to losses arising from collateral liquidation or other loan collection actions, but would be permitted for deed-in-lieu and short-sale transactions. Again, the aim here would be to afford a limited-purpose buffer, where capital regulation is concerned, so as to eliminate inadvertently regulation-induced reluctance on the part of financial institutions to assist in the cleanup of currently dysfunctional underwater mortgage markets.

\section{B. Writing-Down Non-Mortgage Debt}

Turning now to non-mortgage debt, there is at least one form about which at least something should probably be done, even if the problems that it occasions be dwarfed by the problems occasioned by mortgage debt. That is student debt, which as noted in Part III above is increasingly cited as a potentially significant problem ahead.

Because, as noted earlier, student debt probably represents approximately $\$ 1$ trillion of the nation's $\$ 25$ trillion private debt overhang, proposals to trim it are not of the same macroeconomic urgency as are the foregoing proposals. It is nevertheless an important and still growing drag upon economic recovery, however, again as noted above, and of course a significant problem for those affected by it. Because the problem is macroeconomically smaller than that posed by mortgage debt, moreover, it should be less expensive to fix.

A number of promising proposals have been made over the past year or two that we believe merit serious consideration. This is partly because they appear to be narrowly tailored to the problem at hand, and partly because they are conditional and moral-hazard-minimizing.

One such proposal, associated with Senator Durbin of Illinois, is to restore bankruptcy-eligibility to privately held student debt, which accounts for about $\$ 86$ billion, or $8.6 \%$, of total student debt. This eligibility had been available prior to Congress's 2005 legislation overhauling the nation's consumer bankruptcy regime, and many in Congress appear now to regret the change. Because bankruptcy affects individuals' longer term credit ratings, it does not seem to be an option to which people would resort blithely; hence moral hazard concerns should be muted. Moreover, by imposing additional conditions e.g., that filers be able to document a history of, say, five years' prior payment on their loans before filing, moral hazard concerns could be addressed yet further. 
A more recent proposal that has received some attention in recent months is the Student Loan Forgiveness Act of 2012, HR 7140 ("Forgiveness Act"), proposed in the House of Representatives in March of last year. Introduced by Representative Hansen Clarke of Michigan, the Bill would forgive residual student debt owed after ten years' payment of $10 \%$ of annual disposable income for qualifying debtors - what has come to be called the "10-10 plan." The payment history requirement is obviously prompted, as ever, by moral hazard concerns.

While some worry that the plan's not distinguishing between higher and lower tuition-financing loans will encourage profligate choices of school, this strikes us as possibly overblown in light of higher tuitions' correlation to higher incomes, ${ }^{100}$ up to $10 \%$ of which per annum would have to be paid by qualifying debtors. If we are wrong about this, however, required payments could be indexed in part to tuitions directly rather than solely to post-graduation incomes.

Another aspect of the Forgiveness Act that we find promising is its broadening the eligibility criteria for pre-existing loan forgiveness programs that have not benefitted as many as was originally anticipated. Under the Public Service Loan Forgiveness Program, for example, graduates going into certain public service professions - e.g., as firefighters, teachers in underserved schools, doctors in underserved areas, etc. - can cancel their debts after 10 years' such service. The Forgiveness Act would lower that requirement by half.

Finally, the Act would cap interest on undergraduate debt to $3.4 \%$, and would allow any debtor on privately extended student loans whose debt payments exceeded her income to convert her private debt to Federal Direct Loan debt and then move into the "10-10" plan.

As noted above, we recognize that more study might well be in order before full endorsement of plans such as these will be apt. We do think, however, in view of (a) the importance of the relevant demographic here to future mortgage and consumer demand, (b) the faultlessness of most of the debtors for recently spiking tuition rates, (c) the relative ease with which moral hazard can be minimized, and finally (d) the relative inexpensiveness of the forms of mitigation proposed, these plans are very much worth taking seriously as bases on which to construct viable student loan forgiveness programs. That takes us on to our next and final subpart.

\section{C. "Moral Hazard" and "Evaporating Liquidity"}

Before closing this Part, it will be well to address in their own right two related concerns that we imagine might be raised in virtue of our proposals' being debt forgiveness proposals - viz. "moral hazard" on the one hand, and associated "liquidity evaporation" on the other. Debates over the justice and efficiency of debt forgiveness are of course hardy perennials. Some say that "contracts are contracts," others say some debts are "odious." Some say that write-downs induce moral hazard and

\footnotetext{
100 See, e.g., Robinson, "Bankruptcy, not Forgiveness, for Student Loans," Inside Higher Ed, December 7, 2012, at http://www.insidehighered.com/views/2012/12/07/encourage-bankruptcy-not-forgiveness-studentloans-essay.
} 
reduce credit-availability, others observe that you cannot squeeze blood from turnips. We are not going to settle such time-honored questions once and for all here, any more than the Book of Leviticus or centuries of "law versus equity" have done. But three things that can be said bear special emphasis.

First, owing to asset-price bubbles' status as collective action problems as described above in Part II.A, it is doubtful that many home-buyers, at least, during the bubble years had much choice where buying overvalued homes is concerned. That most homes were overvalued is what rendered the bubble a "bubble," as was the fact, also emphasized above in II.A, that during asset price bubbles even a comparatively small number of speculative buyers can determine the prices that even non-speculative buyers must pay. We also noted, in the preceding subpart, that student debt loads seem similarly unattributable to profligacy or fault on the part of the borrowers. It therefore seems mistaken to blame homeowners or students as a class, or, accordingly, to cast write-downs as per se unfair or morally hazardous. ${ }^{101}$ It also is easy to formulate eligibility criteria and craft debt-forgiveness plans like those described just above in ways that do not encourage "strategic" defaults going forward. ${ }^{102}$

Second, for similar reasons there seems little need to fear long-term liquidity- or creditcontraction in response to debt-forgiveness programs like those offered here. Again as discussed in Part II.A, asset price bubbles inflate only when credit is overabundant. We want, then, some credit-caution in future, just not too much. And we want to get to that "sweet spot" as quickly as possible. ${ }^{103}$ The best way to do this is first to clear out the overhang under which over eleven million American households still struggle, then, where real estate lending is concerned, to ensure that residential MBS PSAs going forward look more like commercial MBS PSAs always have looked - providing in advance for valuesalvaging modifications on scales unanticipated before the most recent crisis, and thereby preempting future need of resort to such methods as those here proposed. ${ }^{104}$ New residential mortgage securitizations assembled since 2010 suggest that the latter change already is underway.

To clear out what earlier securitizations have wrought, though, requires a plan like that outlined above. Counterpart remarks hold of student debt in this sense: insofar as the tuition spikes and slow job growth that have brought on more student debt in recent years are themselves attributable to slump and accordingly to private debt overhang itself, there is reason to anticipate that we won't see a reinflating of student debt loads of not only student debt, but the far larger problem of mortgage debt, is dealt with along the lines proposed above.

\footnotetext{
101 Note in addition that, insofar as the mistake made by many - borrowers, creditors, and regulators alike during the bubble years was to think "home prices can only go up," borrowers were probably the least well situated to see the falsity of that adage. If even lenders and regulators were able to believe such a thing - and to aver it publicly while cloaked in the mantle of expertise - it is hardly surprising that some borrowers would come to believe it as well.

102 See Hockett, "It Takes a Village," supra note 2; Hockett, "Paying Paul," supra note 2; and Alpert, Hockett, $\&$ Roubini, supra note 1 , for more on these matters.

103 Idem. Note also that, insofar as our most recent bubble, like that of the 1920s, was a particularly traumatic and "once in a lifetime" affair, it seems a stretch to suppose that clearing the wreckage will issue immediately in a gratuitous resumption of that which ended in 2006.

104 See Hockett, "Six Years On," supra note 56, for more on the differences between RMBS and CMBS PSAs.
} 
Finally, the third point to make here is simply a reminder that write-downs are done on nonmortgage, non-student debt - in particular, corporate debt - all the time, presumably in recognition both of the fact that one cannot squeeze blood from turnips, and of the fact that workouts can be crafted in ways that minimize moral hazard and liquidity loss. We call it bankruptcy, and (a) afford it to firms precisely because it salvages value at minimal expense, while (b) we also afforded it for private student debt until 2005. The plans here proposed do the same. And as noted above, the value thus saved can be shared among all classes of stakeholder, since creditors too benefit by EV-raising writedowns of deeply underwater loans.

\section{Conclusion: The Road Ahead}

We have of course covered a good bit of ground here. But there is obviously much more to do. In effect, we have at best shown that it must be done, why it must be done, and a few hints on how it might be done. We see no way, short of measures of the kind sketched in Part IV, of avoiding permanent serial operation of the mechanism elaborated in Part II. And since each iteration seems destined to outdo its predecessor in the sequence, that means in turn that the bleak present picture laid out in Part III will be the best that we can expect till we act. Our hope is that we have both shown this and shown the way out. 